\title{
geodiversitas

On unreported historical specimens of marine arthropods from the Solnhofen and Nusplingen Lithographic Limestones (Late Jurassic, Germany) housed at the Museum national d'thistoire naturelle, Paris

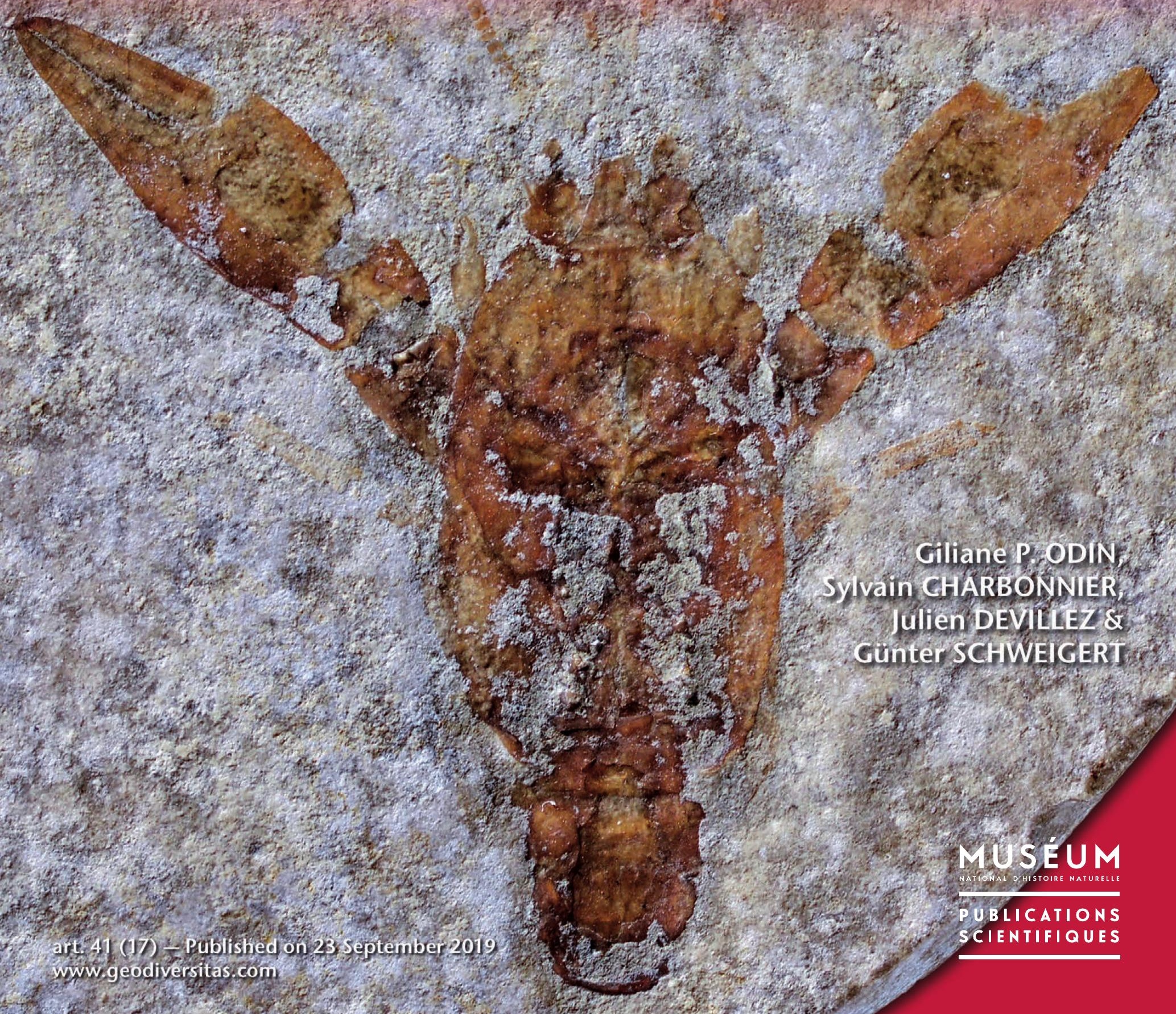


DiRECTEUR DE LA PUBLICATION: Bruno David,

Président du Muséum national d'Histoire naturelle

RÉdACTEUR EN CHEF / EDITOR-IN-CHIEF: Didier Merle

ASSISTANTS DE RÉDACTION / AsSISTANT EDITORS: Emmanuel Côtez (geodiv@mnhn.fr); Anne Mabille

MISE EN PAGE / PAGE LAYOUT: Emmanuel Côtez

COMITÉ SCIENTIFIQUE / SCIENTIFIC BOARD:

Christine Argot (MNHN, Paris)

Beatrix Azanza (Museo Nacional de Ciencias Naturales, Madrid)

Raymond L. Bernor (Howard University, Washington DC)

Alain Blieck (chercheur CNRS retraité, Haubourdin)

Henning Blom (Uppsala University)

Jean Broutin (UPMC, Paris)

Gaël Clément (MNHN, Paris)

Ted Daeschler (Academy of Natural Sciences, Philadelphie)

Bruno David (MNHN, Paris)

Gregory D. Edgecombe (The Natural History Museum, Londres)

Ursula Göhlich (Natural History Museum Vienna)

Jin Meng (American Museum of Natural History, New York)

Brigitte Meyer-Berthaud (CIRAD, Montpellier)

Zhu Min (Chinese Academy of Sciences, Pékin)

Isabelle Rouget (UPMC, Paris)

Sevket Sen (MNHN, Paris)

Stanislav Štamberg (Museum of Eastern Bohemia, Hradec Králové)

Paul Taylor (The Natural History Museum, Londres)

COUVERTURE / COVER:

Eryma modestiforme (Schlotheim, 1822) from the Late Jurassic Solnhofen Lithographic Limestones (Bavaria, Germany), specimen MNHN.F.A32408 from Eichstätt

Geodiversitas est indexé dans / Geodiversitas is indexed in:

- Science Citation Index Expanded (SciSearch ${ }^{\circledR}$ )

- ISI Alerting Services ${ }^{\circledR}$

- Current Contents ${ }^{\circledR}$ / Physical, Chemical, and Earth Sciences ${ }^{\circledR}$

- Scopus ${ }^{\circledR}$

Geodiversitas est distribué en version électronique par / Geodiversitas is distributed electronically by:

- BioOne ${ }^{\circledR}$ (http://www.bioone.org)

Les articles ainsi que les nouveautés nomenclaturales publiés dans Geodiversitas sont référencés par / Articles and nomenclatural novelties published in Geodiversitas are referenced by:

- ZooBank ${ }^{\circledR}$ (http://zoobank.org)

Geodiversitas est une revue en flux continu publiée par les Publications scientifiques du Muséum, Paris Geodiversitas is a fast track journal published by the Museum Science Press, Paris

Les Publications scientifiques du Muséum publient aussi / The Museum Science Press also publish:

Adansonia, Zoosystema, Anthropozoologica, European Journal of Taxonomy, Naturae, Cryptogamie sous-sections Algologie, Bryologie, Mycologie.

Diffusion - Publications scientifiques Muséum national d'Histoire naturelle

CP $41-57$ rue Cuvier F-75231 Paris cedex 05 (France)

Tél. : 33 (0)1407948 05 / Fax: 33 (0)14079 3840

diff.pub@mnhn.fr / http://sciencepress.mnhn.fr

(C) Publications scientifiques du Muséum national d'Histoire naturelle, Paris, 2019

ISSN (imprimé / print): 1280-9659/ ISSN (électronique / electronic): 1638-9395 


\title{
On unreported historical specimens of marine arthropods from the Solnhofen and Nusplingen Lithographic Limestones (Late Jurassic, Germany) housed at the Muséum national d'Histoire naturelle, Paris
}

\author{
Giliane P. ODIN \\ Centre de Recherche en Paléontologie (CR2P, UMR 7207), Sorbonne Université, MNHN, CNRS, \\ Muséum national d'Histoire naturelle, Département Origines et Évolution, \\ case postale 38, 57 rue Cuvier, F-75231 Paris cedex 05 (France) \\ and Laboratoire Milieux Environnementaux, Transferts et Interactions dans les hydrosystèmes \\ et les Sols (METIS, UMR 7619), Sorbonne Université, CNRS, EPHE, \\ Faculté des Sciences et d'Ingénierie, 4 place Jussieu, F-75005 Paris (France) \\ giliane.odin@mnhn.fr \\ Sylvain CHARBONNIER \\ Julien DEVILLEZ \\ Centre de Recherche en Paléontologie (CR2P, UMR 7207), Sorbonne Université, MNHN, CNRS, \\ Muséum national d'Histoire naturelle, Département Origines et Évolution, \\ case postale 38, 57 rue Cuvier, F-75231 Paris cedex 05 (France) \\ sylvain.charbonnier@mnhn.fr \\ Günter SCHWEIGERT \\ Staatliches Museum für Naturkunde, Rosenstein 1, 70191 Stuttgart (Germany)
} guenter.schweigert@smns-bw.de

Submitted on 5 April 2019 | accepted on 24 April 2019 | published on 23 September 2019

Odin G. P., Charbonnier S., Devillez J. \& Schweigert G. 2019. - On unreported historical specimens of marine arthropods from the Solnhofen and Nusplingen Lithographic Limestones (Late Jurassic, Germany) housed at the Muséum national d'Histoire naturelle, Paris. Geodiversitas 41 (17): 643-662. https://doi.org/10.5252/geodiversitas2019v41a17. http://geodiversitas.com/41/17

KEY WORDS

Crustacea,

Decapoda,

Jurassic,

Plattenkalk,

Solnhofen,

Nusplingen,

Germany,

collections,

conservation.

\section{ABSTRACT}

We report and illustrate several unpublished fossil specimens of marine arthropods, housed at the Muséum national d'Histoire naturelle in Paris (France) and coming from the Solnhofen and Nusplingen Lithographic Limestones (Late Jurassic, Germany). Notably, we describe specimens of Antrimpos undenarius Schweigert, 2001, Eryma modestiforme (Schlotheim, 1822) and Mecochirus longimanatus (Schlotheim, 1820). Mecochirus foresti Secrétan, 1968 is considered as a junior synonym of Mecochirus longimanatus. A revision of the specimens previously described is also realized. This contribution thus provides new information on the Antrimpos species from the Solnhofen Plattenkalks and gives a complete overview of the fossil marine arthropods coming from these Plattenkalks which are available at the MNHN. 


$\begin{array}{cl} & \text { RÉSUMÉ } \\ & \text { Sur des spécimens historiques inédits d'arthropodes marins des Calcaires Lithographiques de Solnhofen et } \\ & \text { Nusplingen (Jurassique supérieur, Allemagne) conservés au Muséum national d'Histoire naturelle, Paris. } \\ & \text { Plusieurs spécimens fossiles d'arthropodes marins inédits, conservés au Muséum national d'Histoire } \\ \text { nOTS CLÉS } & \text { naturelle à Paris (France) et provenant des Calcaires lithographiques de Solnhofen et de Nusplingen } \\ \text { Crustacea, } & \text { (Jurassique supérieur, Allemagne), sont décrits et illustrés. Nous décrivons notamment des spécimens } \\ \text { Decapoda, } & \text { d'Antrimpos undenarius Schweigert, 2001, d'Eryma modestiforme (Schlotheim, 1822) et de Mecochirus } \\ \text { Jurassique, } & \text { longimanatus (Schlotheim, 1820). Mecochirus foresti Secrétan, } 1968 \text { est considéré comme un syno- } \\ \text { Plattenkalk, } & \text { nyme plus récent de Mecochirus longimanatus. Une révision des spécimens décrits précédemment } \\ \text { Solnhofen, } & \text { nusplingen, } \\ \text { Allemagne, } & \text { est également réalisée. Cet article fournit ainsi de nouvelles informations sur les espèces d'Antrimpos } \\ \text { collections, } & \text { présentes dans les Plattenkalks de Solnhofen et donne un aperçu complet des arthropodes marins } \\ \text { conservation. } & \text { fossiles provenant de ces localités et disponibles au MNHN. }\end{array}$

\section{RÉSUMÉ}

Nusplingen (Jurassique supérieur, Allemagne) conserues au Muséum national d'Histoire naturelle, Paris. Plusieurs spécimens fossiles d'arthropodes marins inédits, conservés au Muséum national d'Histoire naturelle à Paris (France) et provenant des Calcaires lithographiques de Solnhofen et de Nusplingen (Jurassique supérieur, Allemagne), sont décrits et illustrés. Nous décrivons notamment des spécimens d'Antrimpos undenarius Schweigert, 2001, d'Eryma modestiforme (Schlotheim, 1822) et de Mecochirus longimanatus (Schlotheim, 1820). Mecochirus foresti Secrétan, 1968 est considéré comme un synonyme plus récent de Mecochirus longimanatus. Une révision des spécimens décrits précédemment fossiles provenant de ces localités et disponibles au MNHN.

\section{INTRODUCTION}

The fossil record of marine arthropods delivered by Plattenkalks is particularly diverse and spans several continents (Africa, South America, North America, Europe) and geological era (Cretaceous, Jurassic, Carboniferous). Among these Plattenkalks, the Solnhofen Lithographic Limestones (Bavaria, Germany) are particularly remarkable and deliver beautifully preserved specimens of decapod crustaceans, stomatopods, mysidaceans, and xiphosurans (about 130 taxa; Arratia et al. 2015).

The collection of marine arthropods coming from Solnhofen at the Muséum National d'Histoire Naturelle (MNHN, Paris, France) is the result of 250 years of accumulation, ensuing from exchanges with German institutions, wars pillage, purchases and donations (Charbonnier \& Garassino 2012). Most of the specimens have been described in a previous paper (Charbonnier \& Garassino 2012) but here, we report other specimens discovered in the MNHN collections, notably several specimens of the penaeid shrimp Antrimpos undenarius Schweigert, 2011 from the d'Orbigny collection.

This collection, assembled by the French naturalist Alcide d'Orbigny (1802-1857), was purchased by the MNHN and specimens were inventoried in a catalogue composed of 27 fascicles (Lauriat-Rage 2002). In 1898, a dedicated room (called after his name) was allocated in the newly built Gallery of Palaeontology: "la salle d'Orbigny". However, the moving of the invertebrate collections, including arthropods, to another building in 2019-2020 required to map beforehand these collections and has led to the discovery of historical specimens that have not been published before.

\section{MATERIAL AND METHODS}

\section{COLLECTION ARRANGEMENT}

As introduced by Charbonnier \& Garassino (2012), the fossils housed in the National Museum of Natural His- tory (MNHN; Paris, France) are dispersed between several collections and buildings, explaining why new specimens are regularly discovered. Because all the paleontological specimens housed at the MNHN will soon move in a single building, a mapping of the invertebrate collections has been realized. As a result, unreported historical specimens of marine arthropods from the Solnhofen Lithographic Limestones were discovered in the drawers of the institution and are the subject of this paper. The specimens already described by Charbonnier \& Garassino (2012) will not be mentioned, unless the fossils are reattributed to new taxa.

\section{Fossil LOCALITIES}

Our localities encompass Late Jurassic marine Plattenkalks (i.e. very finely grained limestone precipitated under quiet conditions) of southern Germany (see Audo et al. 2014a: fig. 1, for localization) where soft-bodied fossils, including arthropods, were preserved in lagoonal calcareous muds. The diversity of organisms is exceptionally important and the quality of the record is remarkable. Among marine arthropods, taxa such as penaeoidean and caridean shrimps, polychelidan, erymid and glypheid lobsters have notably been recorded (for general reviews see Garassino \& Schweigert 2006, Schweigert 2011; Charbonnier \& Garassino 2012; Winkler 2012; Schweigert et al. 2016).

The Solnhofen Lithographic Limestones, ranging from the late Kimmeridgian to the early Tithonian (Schweigert 2007), are located in the southern Franconian Alb (SW Germany). They include a large set of localities yielding Plattenkalks, such as Eichstätt, Painten, Solnhofen, globally referred to as "Solnhofen" in many old collections (Garassino \& Schweigert 2006). Used since the late Stone Age as construction stones, fossils were traded by the quarrymen from the 18th century (Barthel et al. 1990: 4-10). These Plattenkalks deliver marine and terrestrial remains, among which jellyfish and feathered dinosaurs 
(the famous Archaeopteryx) are probably the most remarkable ones. Polychelidan, erymid and glypheoidean lobsters as well as caridean and penaeoidean shrimps account for the majority of Solnhofen crustaceans, the latter being the most abundant (Barthel et al. 1990: 129). Among xiphosurans, we can cite the Mesolimulus species, which is one of the best-known marine arthropods encountered in Solnhofen (Barthel et al. 1990: 138).

The Nusplingen Lithographic Limestone is a small fossil Lagerstätte, from the late Kimmeridgian, located in the western part of the Swabian Alb (SW Germany). The site includes two close quarries and delivers over 400 taxa of microfossils, land plants, invertebrates, vertebrates and ichnofossils remains (Dietl \& Schweigert 2004, 2011). The first fossils from the Nusplingen Lithographic Limestone were reported in the middle of the 19th century (Fraas 1855), and after a commercial use of the limestones, it is now a Protected Excavation Area dedicated to scientific excavation (Dietl \& Schweigert 2004). Well-preserved caridean and penaeoidean shrimps and polychelidan lobsters, are typical of the Nusplingen Plattenkalk.

\section{SySTEMATICS}

The following list of Decapoda and Mysidacea crustaceans and limulids (Xiphosurida) housed in the MNHN is arranged taxonomically. It includes 117 specimens which are all presented Appendix 1.

\section{ABBREVIATIONS}

Institutions

MNHN.F Muséum national d'Histoire naturelle, Paris, Paleontological collection;

MNHN.GG Muséum national d'Histoire naturelle, Paris, Geology collection;

CM Carnegie Museum of Natural History, Pittsburgh;

SMNS Staatliches Museum für Naturkunde, Stuttgart.

$\begin{array}{ll}\text { Anatomy } & \\ \text { a } & \text { branchiocardiac groove; } \\ \text { ac } & \text { antennal carina; } \\ \text { as } & \text { antennal spine; } \\ \text { a1 } & \text { antennula; } \\ \text { a2 } & \text { antenna; } \\ \text { b } & \text { antennal groove; } \\ \text { b } & \text { hepatic groove; } \\ \text { c } & \text { postcervical groove; } \\ \text { d } & \text { gastro-orbital groove; } \\ \text { di } & \text { diaeresis; } \\ \text { e } & \text { eye; } \\ \mathrm{e}_{1} \text { e } & \text { cervical groove; } \\ \text { egs } & \text { epigastric spine; } \\ \text { gc } & \text { gastro-orbital carina; } \\ \text { hs } & \text { hepatic spine; } \\ \text { ip } & \text { intercalated plate; } \\ \text { Mxp3 } & \text { third maxilliped; } \\ \text { oc } & \text { orbital carina; } \\ \text { P1-P5 } & \text { pereiopods 1-5; } \\ \text { r } & \text { rostrum; } \\ \text { rs } & \text { rostral spines; } \\ \text { sc } & \text { scaphocerite; } \\ \text { ss } & \text { supraorbital spine; } \\ \text { s1-s5 } & \text { pleonal somites 1-5. } \\ & \end{array}$

\section{COMMENTED SYSTEMATIC LIST}

Class MALACOSTRACA Latreille, 1802

Superorder EUCARIDA Calman, 1904

Order DECAPODA Latreille, 1802

Suborder DENDROBRANCHIATA Bate, 1888

Superfamily PENAEOIDEA Rafinesque, 1815

Family AEGERIDAE Burkenroad, 1963

Genus Aeger Münster, 1839

TYPE SPECIES. - Macrourites tipularius Schlotheim, 1822, by subsequent designation of Woods (1925).

Three species are known from the Solnhofen Lithographic Limestones (Schweigert et al. 2016). All are present in the palaeontological collections of the MNHN (Fig. 1).

\section{Aeger tipularius (Schlotheim, 1822)} (Fig. 1A-C)

DiAgNosis (from Schweigert et al. 2016). — Very short smooth rostrum; Mxp3 extremely long, with movable spines; chelate P1-P3; P1-P2 bearing long movable spines; $\mathrm{P} 3$ with spiny chelae; achelate P4-P5 and spineless; P3 slightly larger than P1-P2; well-developed pleopods; uropodal exopod with rounded diaresis.

STUdied MATERIAL. - Charbonnier \& Garassino (2012) listed seven specimens. Careful examination leads us to re-identify some of them. Three specimens, MNHN.F.A33509 (Solnhofen), B13443 (Eichstätt), MNHN.GG.2004/8072 (unknown locality), are maintained as $A$. tipularius, while four others are attributed to Aeger spinipes (Desmarest, 1817), A. insignis (Oppel, 1862), and Acanthochirana cordata (Münster, 1839).

\section{COMments}

Our assignation is based on the very short and smooth rostrum. The carapace groove pattern typical of Aeger - with a cervical groove steeply inclined, not joined to the dorsal margin but joined to the antennal groove; an oblique and sinuous branchiocardiac groove crossing all the carapace from the posterior margin to the hepatic region; and a hepatic groove joined anteriorly to the cervical groove and posteriorly to the branchiocardiac groove (see diagnosis in Charbonnier et al. 2017: 36) - is particularly visible on specimen A33509 (Fig. 1A, B).

Aeger spinipes (Desmarest, 1817)

(Fig. 1D)

DIAGNOSIS (from Schweigert et al. 2016). - Extremely elongate rostrum, with one medium ventral tooth; Mxp3 extremely long, with movable spines; chelate P1-P3; P1-P2 bearing long movable spines; P3 with smooth chelae; achelate P4-P5 and spineless; P3 slightly larger than P1P2; well-developed pleopods; uropodal exopod with rounded diaresis.

Studied MATERIAL. - Charbonnier \& Garassino (2012) listed and figured only one specimen (MNHN.F.B13441, Eichstätt). We add two specimens from Solnhofen, MNHN.F.B13440, B13442 (Fig. 1D), formerly identified as A. tipularius.

\section{COMMENT}

Our assignation is based on the extremely elongate rostrum. 

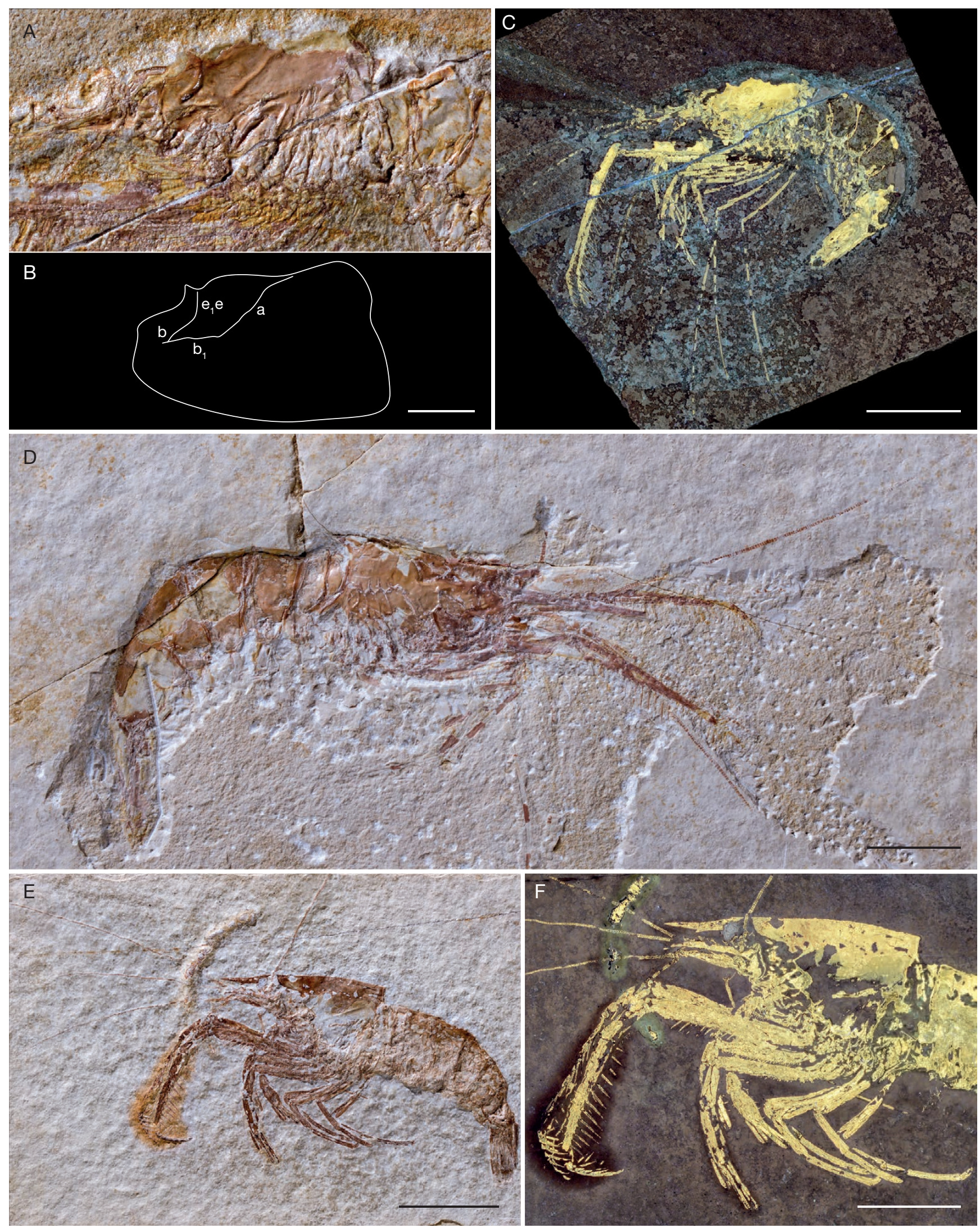

FIG. 1. - A-C, Aeger tipularius (Schlotheim, 1822), specimen MNHN.F.A33509 from Solnhofen; A, natural light; B, interpretation of the carapace grooves; C, UV light; D, Aeger spinipes (Desmarest, 1817), specimen MNHN.F.B13442 from Solnhofen; E, F, Aeger insignis Oppel, 1862, specimen MNHN.GG.2004/57291 from Solnhofen; E, natural light; F, UV light. Scale bars: A, C, $1 \mathrm{~cm} ; \mathrm{B}, \mathrm{D}, 2 \mathrm{~cm} ; \mathrm{E}, 3 \mathrm{~cm}$. Abbreviations: $\mathbf{a}$, branchiocardiac groove; $\mathbf{b}$, antennal groove; $\mathbf{b}_{1}$, hepatic groove; $\mathbf{e}_{1} \mathbf{e}$, cervical groove. Photographs: L. Cazes. Line drawing: G.P. Odin. 

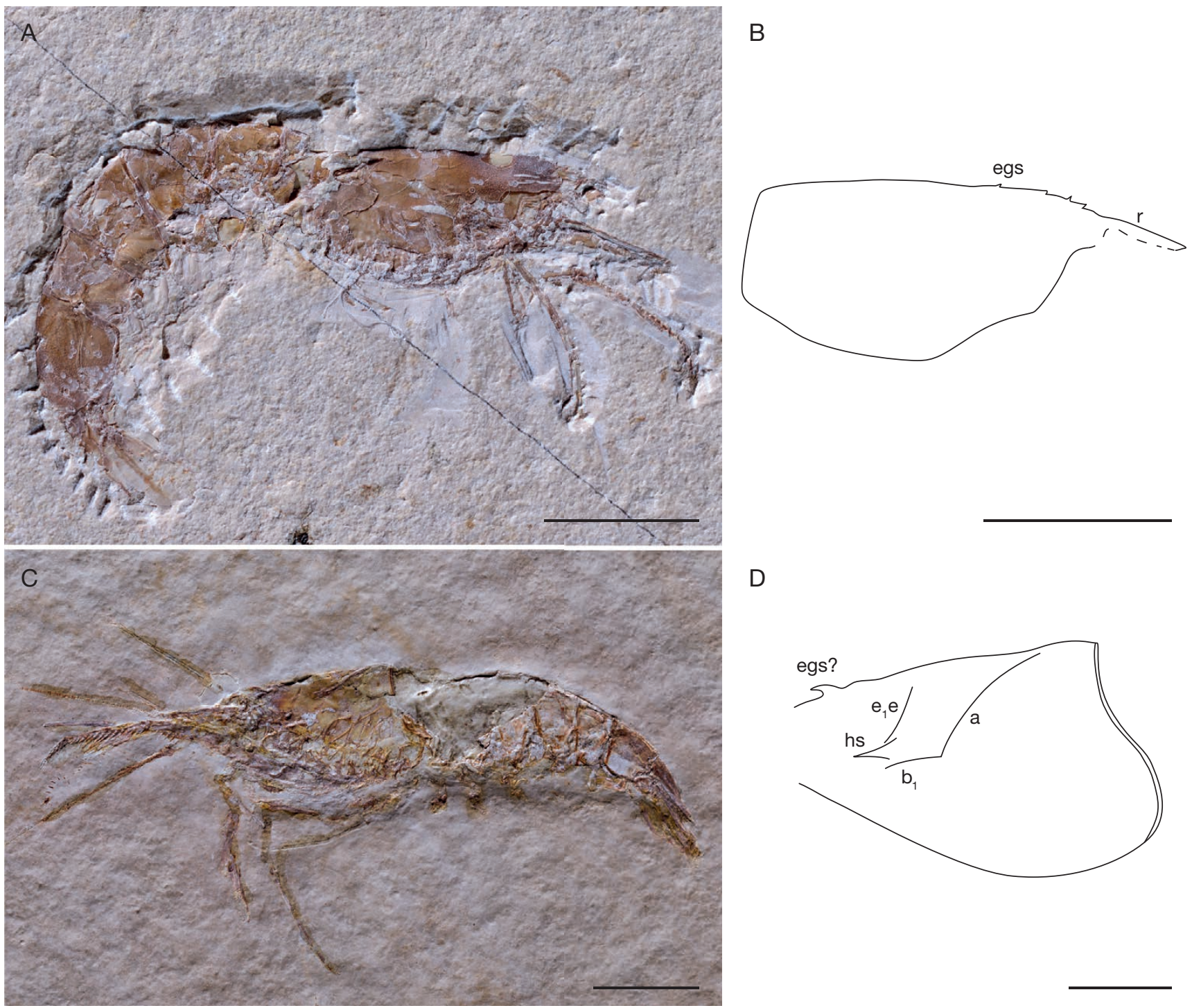

D

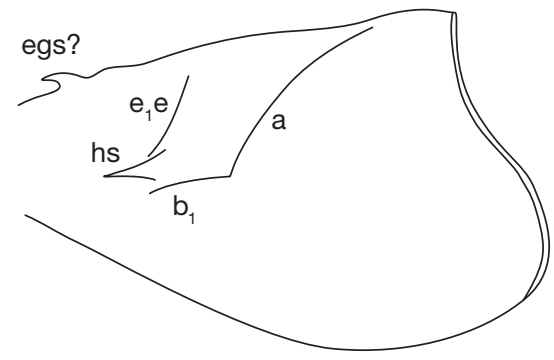

FIG. 2. - Acanthochirana cordata (Münster, 1839): A, B, specimen MNHN.F.A33503 from Solnhofen; A, natural light; B, interpretation of the carapace; C, D, specimen MNHN.F.R03389 from Solnhofen; C, visible light; D, interpretation of the carapace. Scale bars: A, B, D, $1 \mathrm{~cm}$; C, $2 \mathrm{~cm}$. Abbreviations: a, branchiocardiac groove; $\mathbf{b}_{\mathbf{1}}$, hepatic groove; $\mathbf{e}_{\mathbf{1}} \mathbf{e}$, cervical groove; egs, epigastric spine; hs, hepatic spine; $\mathbf{r}$, rostrum. Photographs: L. Cazes. Line drawing: G.P. Odin.

\section{Aeger insignis Oppel, 1862 (Fig. 1E, F)}

Diagnosis (from Schweigert et al. 2016). — Short rostrum, with one ventral tooth distally; Mxp3 extremely long, with movable spines; chelate P1-P3; P2 with spiny chelae; P3 with spiny elements and chelae; achelate P4-P5; uropodal exopod with rounded diaresis.

STUdied MATERial. - Charbonnier \& Garassino (2012) did not mention this species. We add one specimen from Solnhofen, MNHN. GG.2004/57291 (formerly identified as A. tipularius).

COMMENT

Our assignation is based on the elongate rostrum bearing one median ventral tooth, particularly visible in UV light (Fig. 1F).

Genus Acanthochirana Strand, 1928

TYPE SPECIES. — Udora cordata Münster, 1839 (partim), by subsequent designation of Glaessner (1929).
Diagnosis (from Charbonnier et al. 2017). — Rostral carina with spines pointing forward; smooth rostrum, spineless; one epigastric spine in the third anterior of dorsal margin; weak cervical groove, not joined to dorsal margin; oblique branchiocardiac groove joined to hepatic groove at level of strong hepatic spine; short hepatic groove backward directed; cephalic region with postorbital spine; hypertrophied Mxp3 with rows of movable spines; branch-like Mxp3 dactylus; chelate P1-P3; achelate P4-P5; uropodal exopod without diaeresis.

\section{Acanthochirana cordata (Münster, 1839)}

(Fig. 2)

STUDIED MATERIAL. - We studied three specimens, MNHN.F.A33503, R03389 (Solnhofen) and A42003 (Eichstätt), respectively attributed by Charbonnier \& Garassino (2012) to Bylgia hexadon Münster, 1839, Aeger tipularius, and Acanthochirana longipes (Oppel, 1862).

\section{COMMENTS}

Charbonnier \& Garassino (2012) identified the specimen MNHN.F.A42003 as A. longipes. Careful examination of this 
specimen leads us to a different identification. Among the criteria listed in the diagnosis by Schweigert et al. (2016), the number of dorsal rostral teeth and the elongation of Mxp3 are the most important to distinguish $A$. cordata from $A$. longipes. Since it was impossible to count the teeth on our specimens, we use the ratio Mxp3 length / cephalothorax length. Based on drawings from Oppel (1862), the ratio is $\leq 1$ for $A$. cordata while $>>1$ for $A$. longipes. The ratio measured on this specimen is of 0.9 , implying an assignation to $A$. cordata.

Specimen A33503 (Fig. 2A, B), previously attributed to Bylgia hexadon, was misidentified: it clearly shows elongate Mxp3 with moveable spines characteristic of aegerid shrimps. More precisely, the length of Mxp3 fits well with those observed in Acanthochirana. Additionally, this specimen shows a spiny rostral carina prolonged by a smooth rostrum and an epigastric spine, which allow us to ascribe the specimen to Acanthochirana cordata.

Specimen MNHN.F.R03389 (Fig. 2C, D), previously attributed to Aeger tipularius, was also misidentified: it clearly shows elongate Mxp3 with moveable spines characteristic of aegerid shrimps but the length of Mxp3 fits well with those observed in Acanthochirana. Also, the carapace groove pattern is typical of Acanthochirana, showing a weak cervical groove not joined to the cervical margin, an oblique branchiocardiac groove joined to the hepatic groove near the strong hepatic spine and a short hepatic groove backward directed (see diagnosis in Charbonnier et al. 2017: 32).

\section{Family PeNAEIDAE Rafinesque, 1815}

\section{Genus Antrimpos Münster, 1839}

TYPE SPECIES. - Antrimpos speciosus Münster, 1839, by subsequent designation of Glaessner(1929).

TRANSLATION OF THE ORIGINAL DIAGNOSIS (from Münster 1839). Antennules short; antennae very long, with a very long scaphocerite; chelate P1-P3, increasing in length, with movable dactyli; cylindric flattened cephalothorax; rostrum dentate; pointed telson and subrounded uropodal exopod.

Translation of THE EMENDED DiagnOsis (from Oppel 1862). Antennules very short, of different length, antennae of twice the length of the body, rostrum dentate, spiny Mxp3; chelate P1-P3, increasing in length, and achelate P4-P5; S5 longest; cuticle smooth except on the dorsal area of the carapace, which is covered with small pits.

TRANSLATION OF THE EMENDED DiAgNOSIS (from Van Straelen 1925). Rostrum dentate - often on both sides; antennules of different length; antennae to twice length of body; chelate P1-P3 and achelate P4-P5.

EMENDED DiAGNOSIS (from Glaessner 1969). - Antennules very short, antennae to twice length of body, rostrum dentate, carapace smooth, thin; length of pereiopods increasing from 1 to 3 ; $6^{\text {th }}$ abdominal somite longest.

EMENDED DiAGNOSIS (from Schweigert et al. 2016). - Carapace subrectangular, laterally flattened; rostrum elongate slightly turned upward distally, with nine dorsal teeth and one ventral tooth distally; epigastric tooth; Mxp3 short and smooth; uropodal exopod with a subrounded diaresis.
EMENDED DIAGNOSIS (present work). - Carapace subrectangular, laterally flattened; elongate rostrum slightly turned upward distally, with several dorsal teeth and one ventral tooth; longitudinal rostral carina; epigastric tooth; postorbital spine; very strong and asymmetrical hepatic spine, with elongate dorsal segment and short ventral one; concave cervical groove rimming the upper segment of hepatic spine; subhorizontal hepatic ridge below hepatic spine; s1-s3 with rounded median lateral processes (subtle in s3); Mxp3 short and smooth; chelate P1-P3, increasing in length, achelate P4-P5; uropodal exopod with a subrounded diaresis.

Antrimpos speciosus Münster, 1839

(Fig. 3)

STUDIED MATERIAL. - Charbonnier \& Garassino (2012) mentioned six specimens: three specimens from Solnhofen (MNHN.F.A33519, A33548, R03502); two specimens from Eichstätt (MNHN.F.A33504, B13465) and one specimen from an unknown locality (MNHN. GG.2004/8086). Collections Boué, de Roissy, Hoffstetter, Manchester Museum, d'Orbigny.

\section{COMMENTS}

Specimen MNHN.F.A33504 (Fig. 3A-C) shows a well-preserved rostrum and a well-marked hepatic spine, while specimen A33519 (Fig. 3G, H) shows evidence of preserved muscle fibres near somites 1 and 2 (see also Briggs et al. 2005). For comparison, specimens from the Carnegie Museum of Natural History (CM-33420; from Robalino et al. 2016; Fig. 3D, E) and from the private collection of Roger Frattigiani (Laichingen, Germany; figured in Schweigert 2015: fig. 568 and Fig. 3F) are also illustrated.

Antrimpos undenarius Schweigert, 2001

(Figs 4; 5)

TRANSLATION OF THE DiAgNOSIS (from Schweigert 2001). — Largesized species of the genus Antrimpos, rostrum with 11 dorsal spines, the posterior one [= hepatical spine] being separated from the others, and one ventral spine located just before the foremost dorsal spine. Long propodite on P3.

STUDied MATERIAL. - Charbonnier \& Garassino (2012) did not mention this species. Nine specimens MNHN.F.A06834, A49608, A49609, A49610, A49615, A49616, A49622, A49623 and A49624 from Nusplingen were re-discovered in the Collection d'Orbigny. All these specimens are labelled "Nusplingen, Mr Béroldingen, $13 \mathrm{e}$ " (Fig. 4A). The family von Beroldingen is an old family of nobles originating from Switzerland; Baron Franz Coelestin von Beroldingen (1740-1798) was known as a mineral and fossil collector and after his death, his nephew, Count Joseph Ignace von Beroldingen (1780-?), sold his mineral collection to the London museum (British Museum of Natural History 1904). In our case, "Mr Béroldingen" refers to Paul Ignaz Josef Graf von Beroldingen (1804-1875), another nephew of Baron von Beroldingen, who offered the Antrimpos specimens from Nusplingen to Alcide d'Orbigny. von Beroldingen probably got them by exchanging fossils with Oscar Fraas (1824-1897) as the two of them knew each other. Indeed, in a letter from 1863, "Mr Béroldingen" mentioned several fossils from the Tertiary of Swabia, including the Jurassic taxon Squatina acanthoderma from Nusplingen, which was described by Oscar Fraas in 1855 (Mayer 1976). Number " $13 \mathrm{e}$ " refers to the thirteenth geological stage of d'Orbigny, which is the Oxfordian. Additional specimens of $A$. undenarius coming from the SMNS collection are presented in Fig. 5 for comparison. 

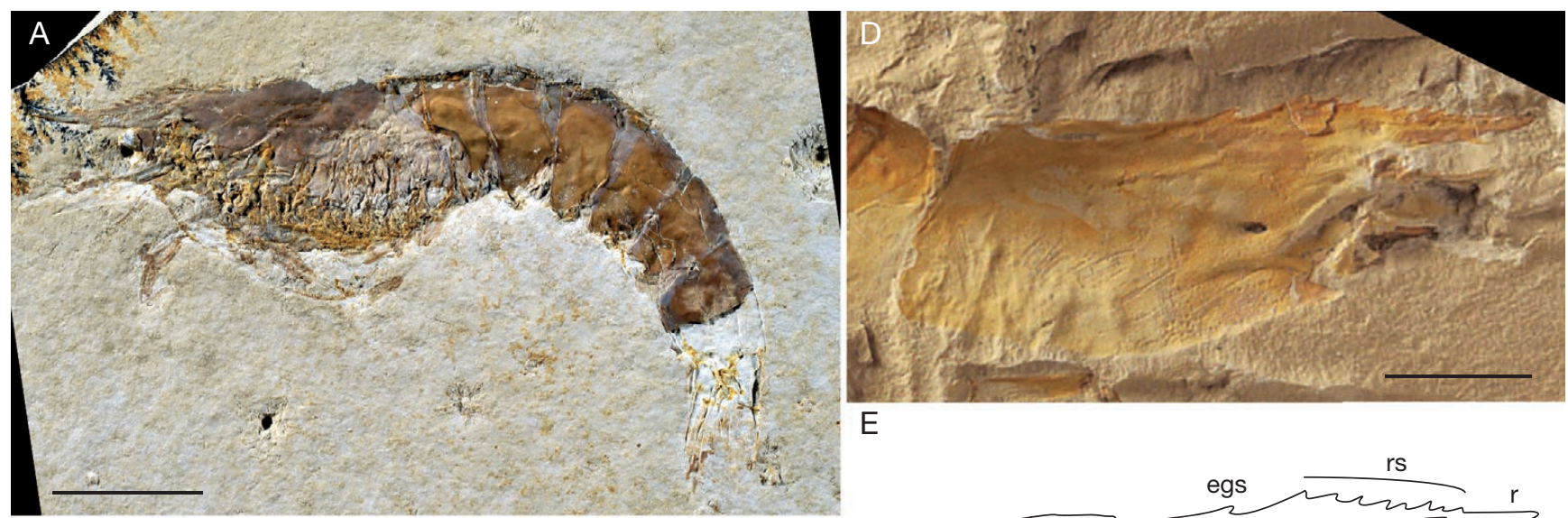

E
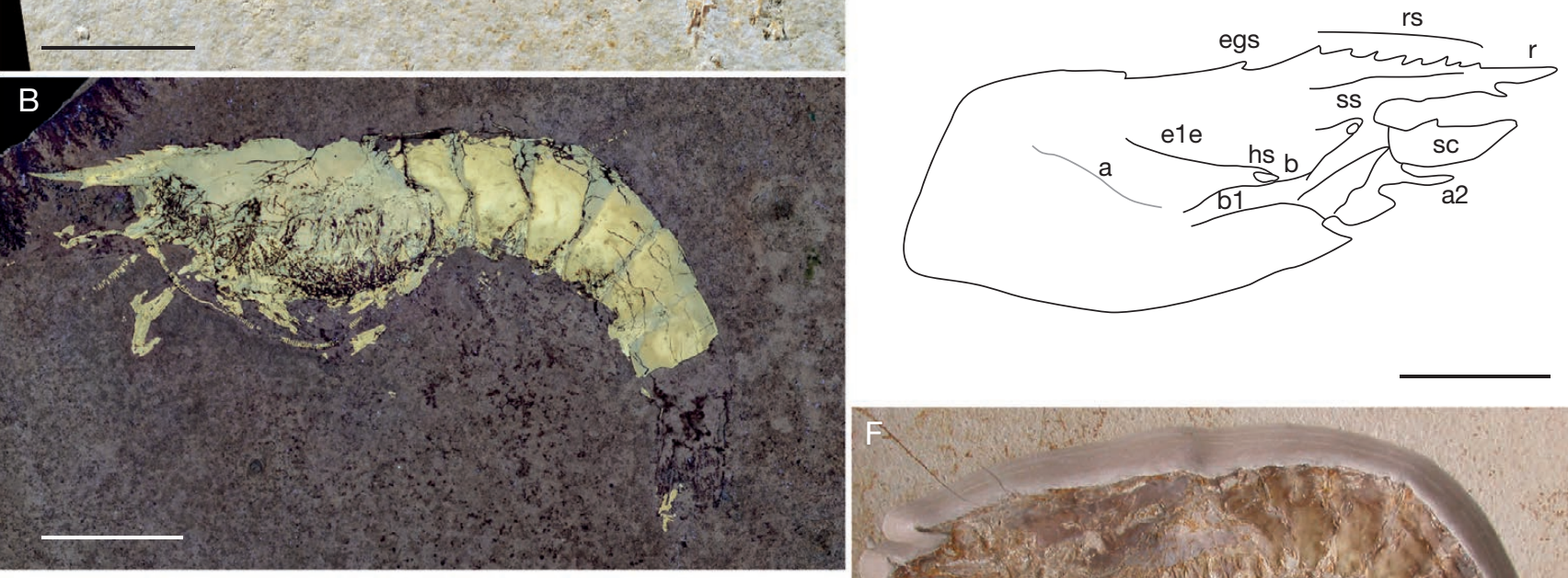

C
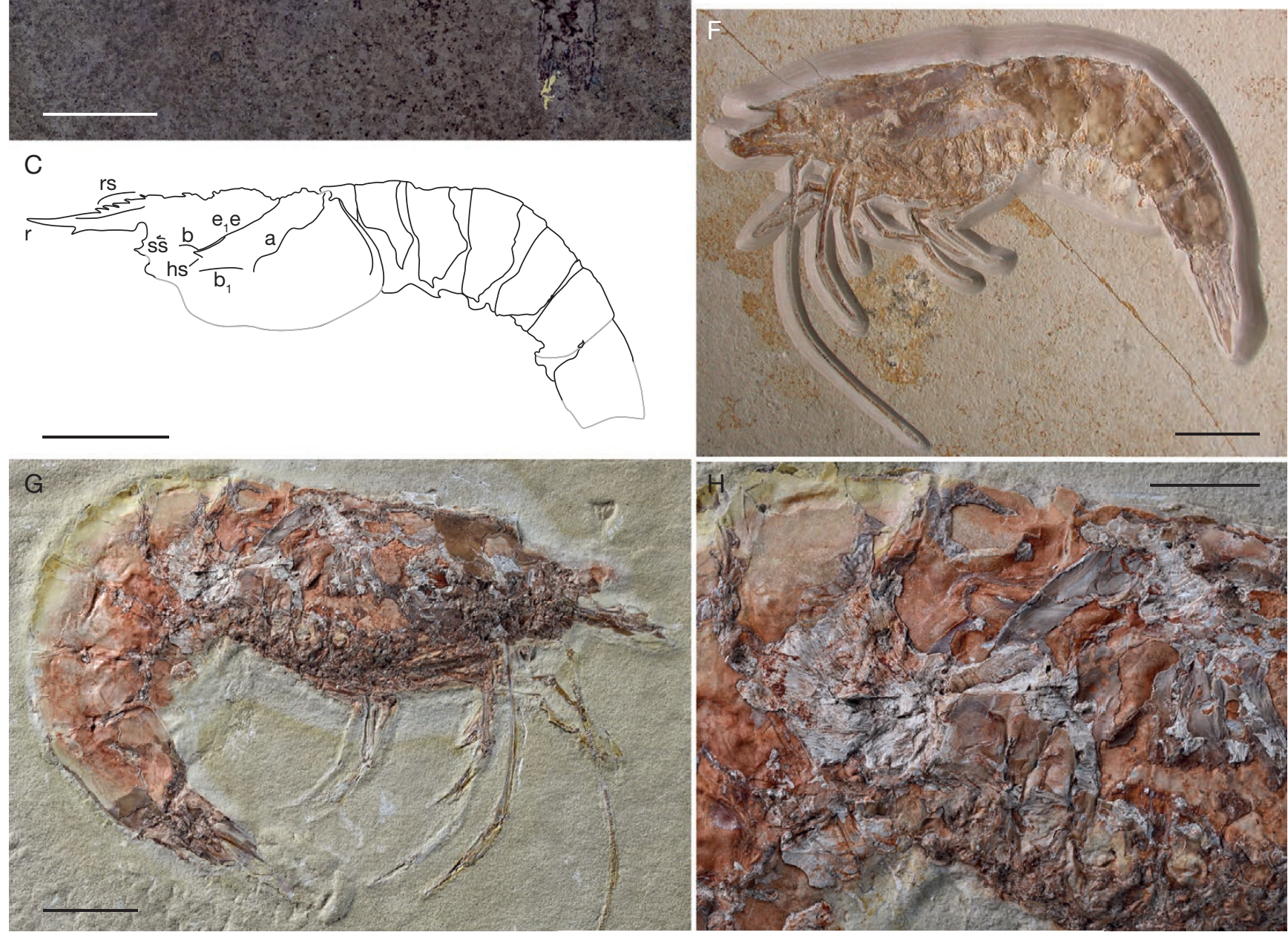

FIG. 3. - Antrimpos speciosus Münster, 1839: A-C, specimen MNHN.F.A33504 from Eichstätt: A, visible light; B, UV light; C, line drawing of the specimen; D, E, specimen CM-33420 likely coming from Solnhofen (Robalino et al. 2016); D, visible light; $\mathbf{E}$, interpretation of the carapace; $\mathbf{F}$, specimen from Solnhofen (illustrated in Schweigert 2015: fig. 568; private collection of Roger Frattigiani); G, H, specimen MNHN.F.A33519 from Solnhofen; G, full view of the specimen; $\mathbf{H}$, close-up of muscle fibers. Abbreviations: $\mathbf{a}$, branchiocardiac groove; $\mathbf{a} 2$, antenna; $\mathbf{b}$, antennal groove; $\mathbf{b}_{\mathbf{1}}$, hepatic groove; $\mathbf{e}_{\mathbf{1}} \mathbf{e}$, cervical groove; egs, epigastric spine; hs, hepatic spine; $\mathbf{r}$, rostrum; rs, rostral spines; sc, scaphocerite; ss, supraorbital spine; Grey line of drawing, hypothesized delimitation. Photographs: L. Cazes (except D: M. McNaugher and F: G. Schweigert). Line drawings: G.P. Odin. Scale bars: A-C, F, G: 2 cm; D, E, H, $1 \mathrm{~cm}$. 


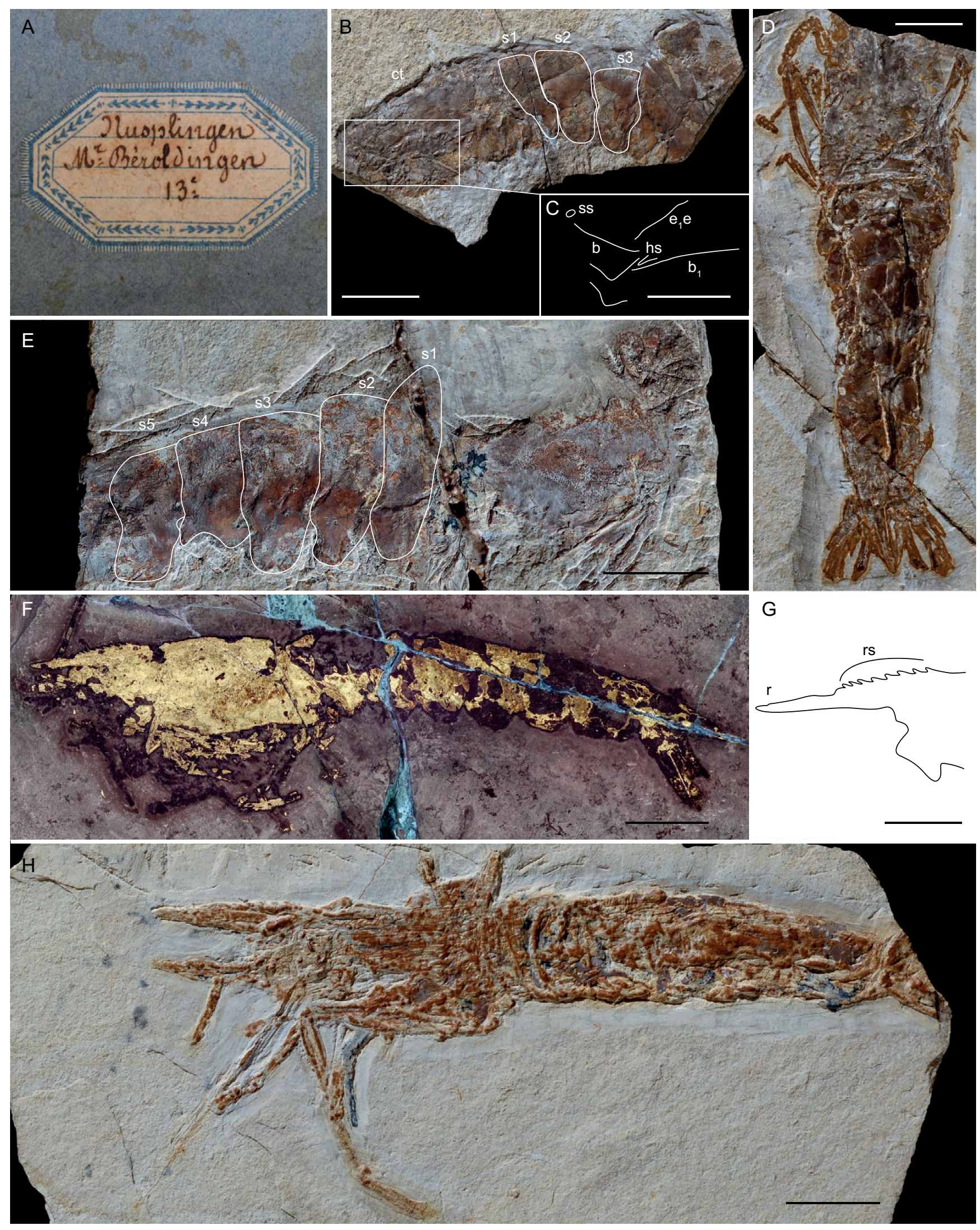

FIG. 4. - Antrimpos undenarius Münster, 1839 from Nusplingen, housed at the MNHN: A, picture of the old label; B, C, specimen MNHN.F.A49615; B, natural light picture; C, line-drawing of the grooves; D, specimen MNHN.F.A49610; E, specimen MNHN.F.A49622; F, G, specimen MNHN.F.A49608; F, UV picture; $\mathbf{G}$, line-drawing of the rostrum; $\mathbf{H}$, specimen MNHN.F.A49624. Abbreviations: $\mathbf{b}$, antennal groove; $\mathbf{b}_{\mathbf{1}}$, hepatic groove; $\mathbf{c t}$, cephalothorax; $\mathbf{e}_{\mathbf{1}} \mathbf{e}$, cervical groove; hs, hepatic spine; $\mathbf{r}$, rostrum; rs, rostral spines; s1-s5, pleonal somites; ss, supraorbital spine. Scale bars: B-F, H, $1 \mathrm{~cm}$; G, 2 cm. Photographs: L. Cazes (except A: G. P. Odin). Line drawing: G. P. Odin. 


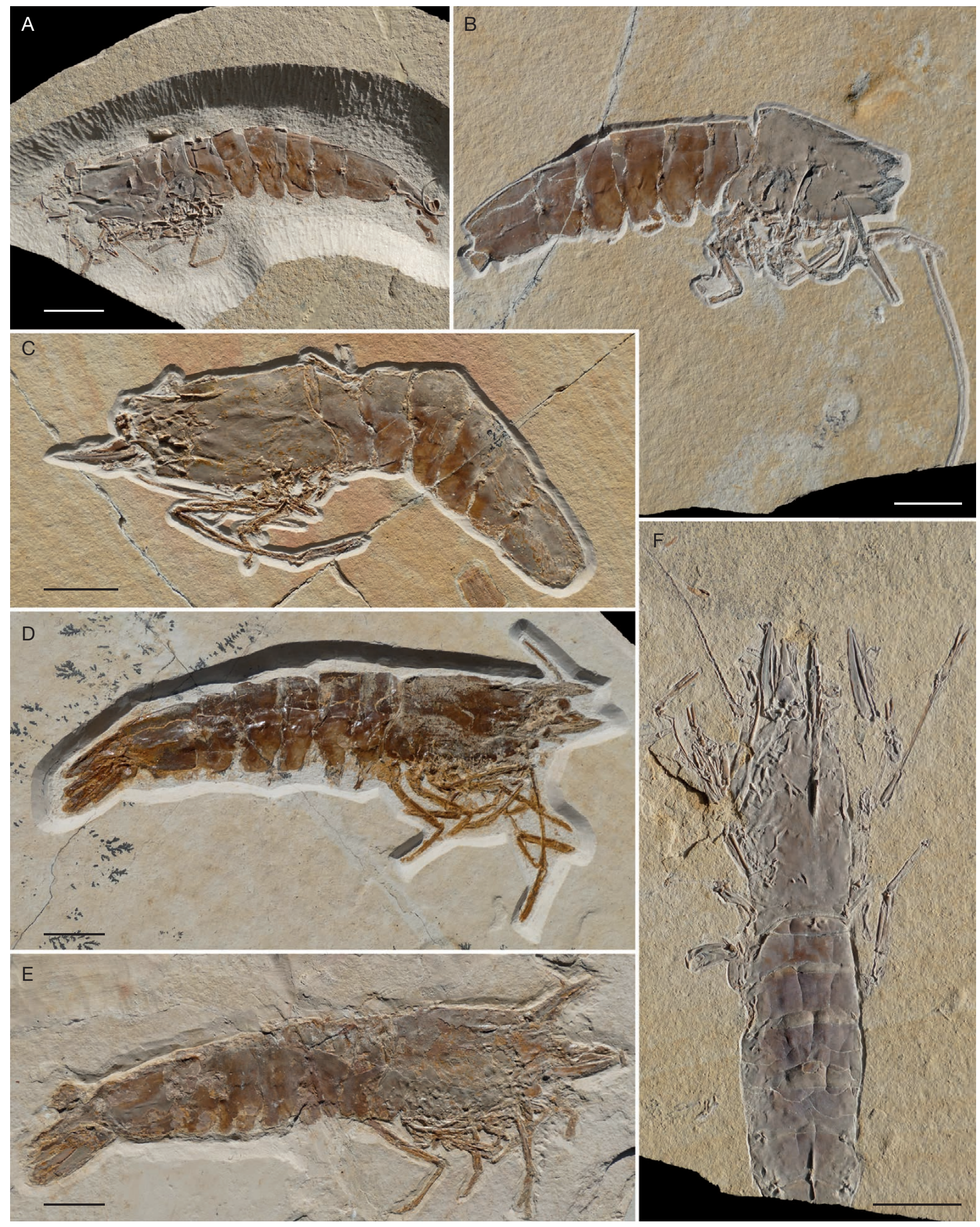

FIG. 5. - Antrimpos undenarius Münster, 1839 from Nusplingen, housed at the SMNS: A, specimen SMNS 80480; B, specimen SMNS 80481; C, specimen SMNS 80482; D, specimen SMNS 80483; E, specimen SMNS 24228; F, specimen SMNS 66122. Scale bars: A-F, 2 cm. Photographs: G. Schweigert. 


\section{COMments}

According to Schweigert (2017), Antrimpos undenarius is the most abundant prawn of the Nusplingen Plattenkalk. The d'Orbigny specimens are characteristically preserved by a coating made of iron oxides (Figs 4B, D, E, H; 5A-E) and embedded in relatively coarse lithographic limestones. The orientation of the corpses (pleon in lateral view and carapace in dorso-ventral view, as in Figs 4H; 5A-C, E) is also characteristic of the fossil prawns from Nusplingen. Thus, the preservation in complete dorsal view, as for A49610 (Fig. 4D) and SMNS 66122 (Fig. 5F) is rather rare. Furthermore, the preservation in $3 \mathrm{D}$ of the rostrum is particularly remarkable on specimens SMNS 80482 and SMNS 66122 (Fig. 5C, F).

On specimens housed at the MNHN, the diagnostic anatomical characters of the species are poorly preserved and observed alternatively in several specimens (Fig. 4C, E, G). For instance, the rostrum with numerous dorsal teeth (Fig. 4G), the strong hepatic spine, the hepatic ridge, the median lateral processes on s1-s3 are typical of Antrimpos. The large size of the specimens is compatible with $A$. undenarius.

\section{Infraorder ASTACIDEA Latreille, 1802 \\ Superfamily ERYMOIDEA Van Straelen, 1925}

Family ERYMIDAE Van Straelen, 1925

\section{PRELIMINARY REMARKS}

Eryma modestiforme (Schlotheim, 1822) (Fig. 6), Palaeastacus fuciformis (Schlotheim, 1822) (Fig. 7) and Pustulina minuta (Schlotheim, 1822) (Fig. 7) are the three most common erymids found in the Solnhofen Lithographic Limestones. Numerous specimens are almost complete, but the compression often impedes the identification of the carapace grooves, which are important for the systematic of the Erymidae. Instead, we use the general ornamentation and the features of the P1 chelae (shape and ornamentation) to distinguish the erymid lobsters. Indeed, $P$. fuciformis and $P$. minuta have P1 chelae with a subrectangular propodus bearing short and wide fingers, while the fingers of $E$. modestiforme are longer than the propodus and are progressively narrowing to their distal extremity. Moreover, E. modestiforme is ornamented by small tubercles and depressions, while $P$. minuta is covered by coarse rounded tubercles and $P$. fuciformis bears strong spines on its carapace and its $\mathrm{P} 1$ propodus.

\section{Genus Eryma Meyer, 1840}

TYPE SPECIES. - Macrourites modestiformis Schlotheim, 1822, by subsequent designation of Glaessner(1929).

\section{Eryma modestiforme (Schlotheim, 1822)} (Fig. 6)

STUDIED MATERIAL. — Charbonnier \& Garassino (2012) listed eight specimens: six specimens coming from Solnhofen (MNHN.F.A33507,
B13448, B13450, B13452, B13463, MNHN.GG.2004/7462), one specimen from Eichstätt (B13446) and one specimen from an unknown locality (MNHN.GG.2004/8078-7471). Only two of them were figured (MNHN.F.B13450 and B13446); we thus figure three other specimens (MNHN.F.A33507, Fig. 6B; B13452, Fig. 6E; and B13463, Fig. 6A) and add three new specimens, one specimen from Eichstätt (MNHN.F.A32408, Fig. 6H); one specimen from Painten (MNHN.F.A70906, Fig. 6G) and one specimen from an unknown locality (MNHN.F.A70905, Fig. 6C). Collections Boué, Schwarzchild, A. Milne-Edwards, Hoffstetter, Manchester Museum, Férussac, Sauzières.

\section{COMMENTS}

Eryma modestiforme and E. veltheimii (Münster, 1839) are the two species encountered in the Solnhofen Lithographic Limestones, the former being the most common. E. modestiforme is known by numerous specimens, almost complete, stored notably in European palaeontological collections (e.g. Paris, Berlin, London, Brussels, Basel). Among the MNHN collection, four specimens clearly show the intercalated plate characteristic of the erymid lobsters: MNHN.F.A32408, A33507, A70905, B13463, B13450 (Fig. 6A-D, H; see also Charbonnier \& Garassino 2012: fig. $3 \mathrm{~b})$. All the specimens exhibit a short $\mathrm{P} 1$ propodus with a dense ornamentation, allowing us to ascribe the fossils to the species $E$. modestiforme (the propodus is more elongate and smooth in E. veltheimii). Moreover, three specimens show additional characters, diagnostic of E. modestiforme: 1) on the specimens MNHN.F.A70905 (Fig. 6C, D) and B13452 (Fig. 6E, F), the carapace groove pattern, in particular the junction between the postcervical and the branchiocardiac grooves (Devillez et al. 2016; Devillez \& Charbonnier 2017), is easily identifiable; and 2) the morphology of the P1 chelae of the specimen MNHN.F.A32408 (Fig. 6H), shows a subrectangular propodus, thin fingers progressively narrowing to their distal extremity and without teeth on their occlusal margins.

The historical specimen MNHN.F.A32408, figured by Desmarest (1822: pl. 11, fig. 5), shows the typical mode of preservation and lithology of the Bavarian Lithographic Limestones (Fig. 6H) but the locality of this specimen may be misleading. Desmarest (1822: 136) refers to "Aichstedt", which is also the locality indicated on the original label, while the locality "Aichtät" is specified on the specimen. In a letter about the Franconian geology to A. Brongniart, L. de Buch (1823) evokes the lithographic limestones exploited at "Eichstedt" and "Solenhofen", in the Altmuhl valley. However, there is no locality spelled "Eichstedt" next to the Altmühl River (instead, Eichstedt (Altmark) is a city located approx. $80 \mathrm{~km}$ west to Berlin) but "Eichstätt". Thus, the designations "Aichtät", "Aichstedt" and "Eichstedt" in the mentioned publications are likely orthographic variations referring to the same locality, nowadays spelled Eichstätt.

\section{Genus Palaeastacus Bell, 1850}

TYPe SPECIES. - Astacus sussexiensis Mantell, 1824, by subsequent designation of Glaessner(1929). 


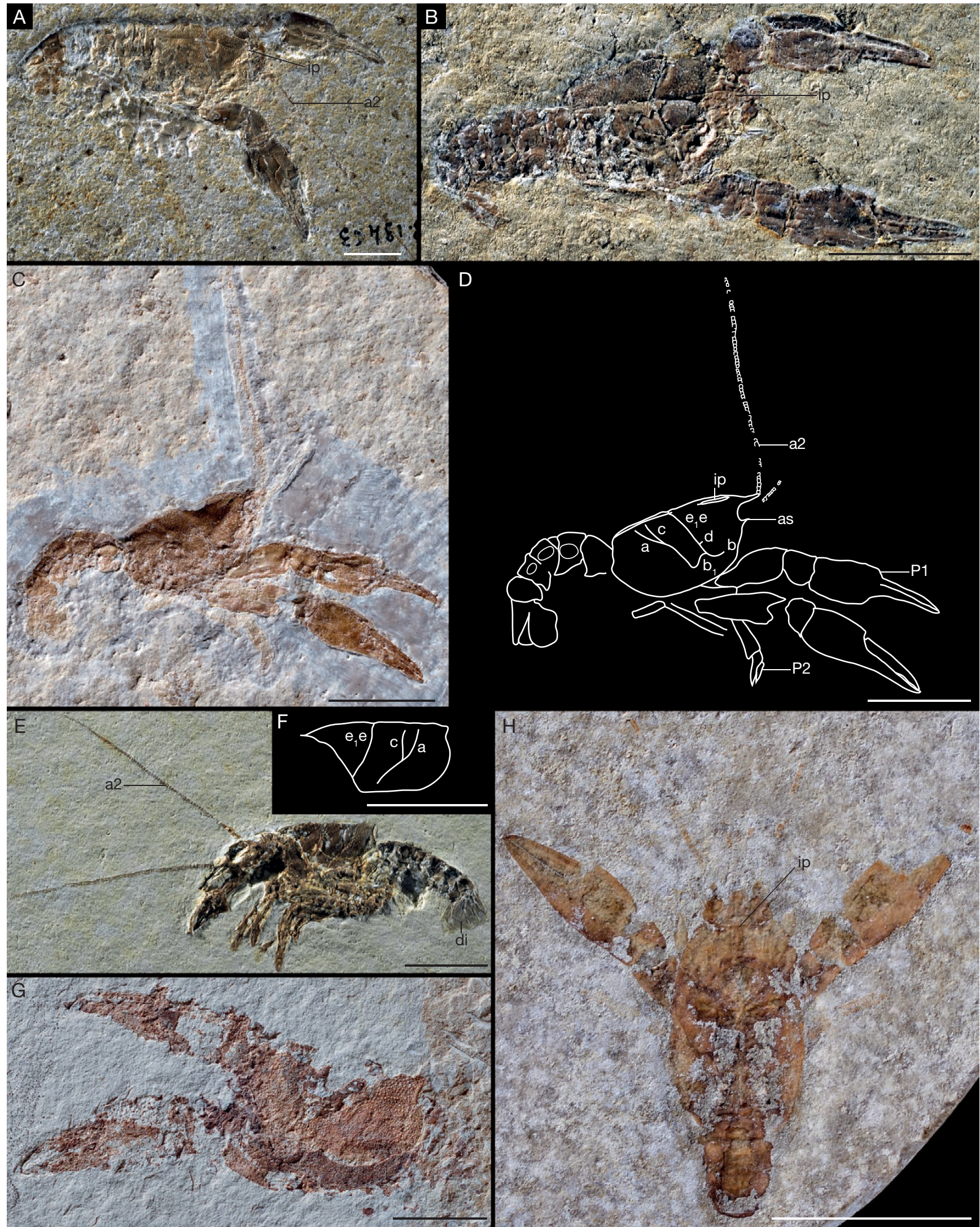

FIG. 6. - Eryma modestiforme (Schlotheim, 1822) from the Late Jurassic Solnhofen Lithographic Limestones (Bavaria, Germany): A, specimen MNHN.F.B13463 from Solnhofen; B, specimen MNHN.F.A33507 from Solnhofen; C, D, specimen MNHN.F.A70905 (unknown locality): general view (C) and line drawing (D); E, F, specimen MNHN.F.B13452 from Solnhofen: general view (E) and line drawing of the carapace (F); G, specimen MNHN.F.A70906 from Painten; H, specimen MNHN.F.A32408 from Eichstätt. Scale bars: A-G, $1 \mathrm{~cm} ; \mathrm{H}, 0.5 \mathrm{~cm}$. Abbreviations: a, branchiocardiac groove; as, antennal spine; a2, antenna; $\mathbf{b}$, antennal groove; $\mathbf{b}_{1}$, hepatic groove; $\mathbf{c}$, postcervical groove; $\mathbf{d}$, gastro-orbital groove; di, diaeresis; $\mathbf{e}_{1} \mathbf{e}$, cervical groove; ip, intercalated plate; P1-P2, periopods 1-2. Preparation: Y. Despres (C). Photographs: C. Lemzaouda (A, B, E), L. Cazes (C, G, H). Line drawings: J. Devillez. 
Palaeastacus fuciformis (Schlotheim, 1822) (Fig. 7A-C)

STUDIED MATERIAL. — Charbonnier \& Garassino (2012) mentioned three specimens: two from Solnhofen (MNHN.F.B13449; MNHN. GG.2004/8245) and one from an unknown locality (MNHN. GG.2004/7998-8106). We do not change their attribution.

\section{COMMENTS}

Since only one specimen (MNHN.F.B13449) was figured by Charbonnier \& Garassino (2012), we additionally figure the specimen MNHN.GG.2004/8245 (Fig. 7A-C), which is particularly well-preserved; notably, the ornamentation is nearly complete.

\section{Genus Pustulina Quenstedt, 1857}

TYPE SPECIES. — Pustulina suevica Quenstedt, 1857, by subsequent designation of Glaessner (1929).

Pustulina minuta (Schlotheim, 1822)

(Fig. 7D)

STUDIED MATERIAL. — Charbonnier \& Garassino (2012) mentioned three specimens: two from Eichstätt (MNHN.F.B13444, B13445) and one specimen from an unknown locality (MNHN. GG.2004/8101). We do not change their attribution.

Family MeCOCHIRIDAE Van Straelen, 1925

Genus Mecochirus Germar, 1827

TYPE SPECIES. - Macrourites longimanatus Schlotheim, 1820, by subsequent designation of Woods (1927).

\section{Mecochirus longimanatus (Schlotheim, 1820)}

(Fig. 8)

STUDied MATERIAL. - Charbonnier \& Garassino (2012) listed 27 specimens including two specimens described as Mecochiria foresti by Secrétan (1968). We add a new specimen from Solnhofen (MNHN.F.A70929).

\section{COMMENTS}

We localized the type material of Mecochiria foresti Secrétan, 1968. She listed five syntypes but figured only two (MNHN.F.A33537: Fig. 8A, B; A33539: Fig. 8F, G), which are dorsoventrally flattened. According to Förster (1971), these specimens show diagnostic characters of Mecochirus longimanatus, and Mecochiria is a junior synonym of Mecochirus. This view was followed by Schweitzer et al. (2010: 20), who, however, maintained Mecochirus foresti as a separate species. Our examination of the two syntypes did not evidence any significant morphological differences to distinguish two species. Hence, we consider $M$. foresti as a junior synonym of $M$. longimanatus.

Specimen MNHN.F.A70929 (Fig. 8C-E) arrived in the MNHN collections in December 1930, through Mr Gravigny, Charles Brongniart's son-in-law. The carapace exhibits the typical cervical groove and the orbital and gastro-orbital carinae. P1 is very elongate and P2 shows a strong and stout propodus as described by Garassino \& Schweigert (2006).

\section{Infraorder POLYCHELIDA Scholtz \& Richter, 1995}

$$
\text { Family ERYONIDAE De Haan, } 1841
$$

\section{PRELIMINARY REMARKS}

To date, the following eryonid species have been reported from the Solnhofen Lithographic Limestones: Cycleryon propinquus (Schlotheim, 1822), Cycleryon orbiculatus (Münster, 1839), Cycleryon elongatus (Münster, 1839), Cycleryon wulf Garassino \& Schweigert, 2004, Eryon cuvieri Desmarest, 1817, Knebelia bilobata (Münster, 1839), Knebelia schuberti (Meyer, 1836), and Knebelia totoroi Audo, Schweigert, Haug, Haug, Saint Martin \& Charbonnier, 2014 (Audo et al. 2014b). Audo et al. (2014a) mentioned additional species including Soleryon schorri from Wattendorf and Soleryon sp. from Zandt.

\section{Genus Cycleryon Glaessner, 1965}

TYPE SPECIES. - Macrourites propinquus Schlotheim, 1822, by original designation.

Cycleryon propinquus (Schlotheim, 1822) (Fig. 9)

STUdied MATERIAL. - Charbonnier \& Garassino (2012) listed five specimens (Appendix 1). We do not change their contribution.

\section{COMMENTS}

The specimen MNHN.F.B13436 (Fig. 9A) is preserved in ventral view and exhibits asymmetrical first pereiopods: the right $\mathrm{P} 1$ presents the usual aspect whereas the left one is much more reduced. According to Van Straelen (1925) and Audo (2014), this physiology is not native but rather due to a regenerative heterochely. The crista dentata (serrated inner margin of the third maxilliped ischium) is visible.

\section{Genus Eryon Desmarest, 1817}

TYPE SPECIES. — Eryon cuvieri Desmarest, 1817, by monotypy.

Eryon cuvieri Desmarest, 1817

(Fig. 9)

STUDIED MATERIAL. - Charbonnier \& Garassino (2012) listed 16 specimens including the lectotype (Appendix 1).

\section{COMMENTS}

Three of the specimens figured are in ventral view (Fig. 9C-G), allowing the observation of nicely preserved details such as 


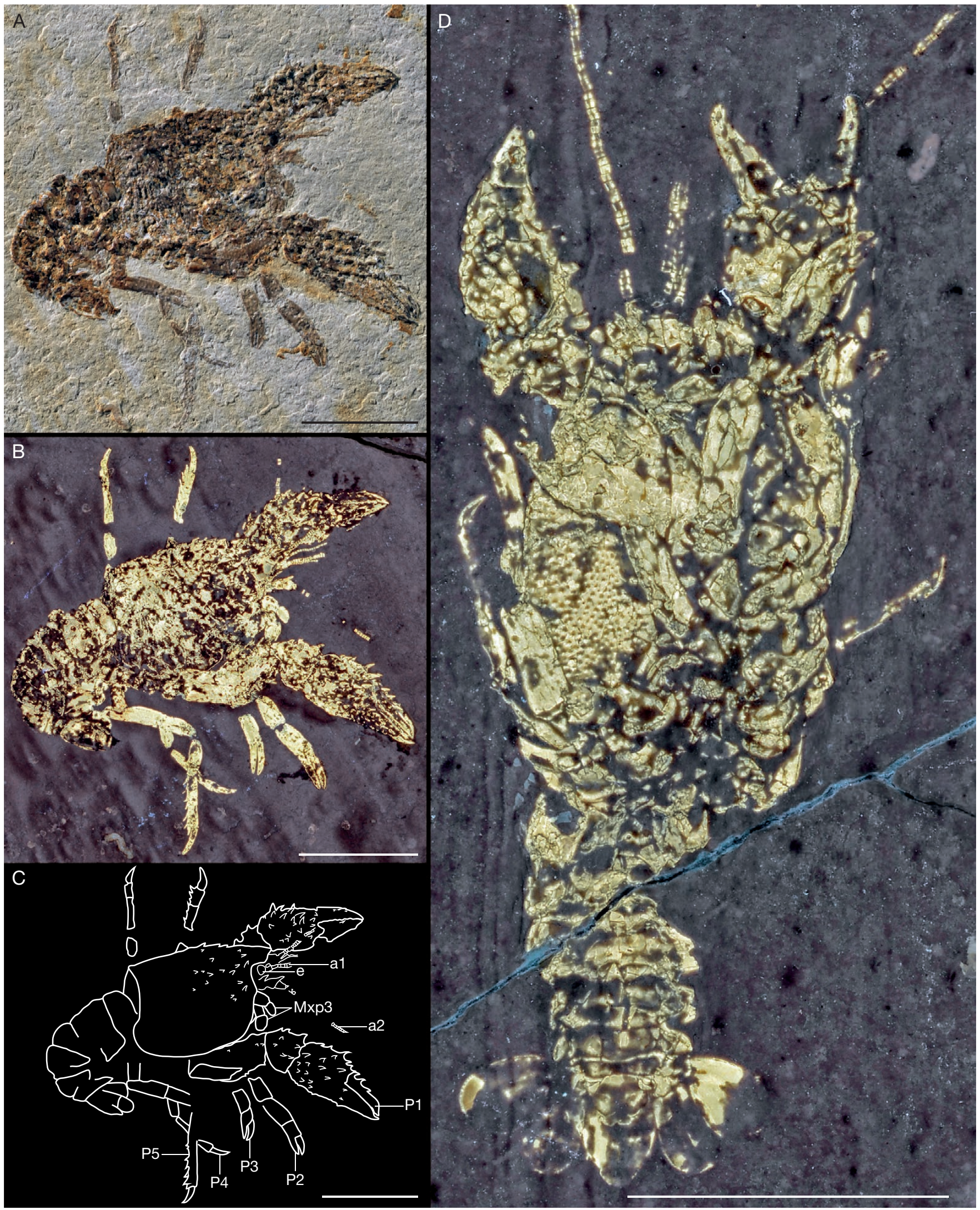

FIG. 7. - Other Erymoidea from the Late Jurassic Solnhofen Lithographic Limestones (Bavaria, Germany): A-C, specimen MNHN.GG.2004/8245 of Palaeastacus fuciformis (Schlotheim, 1822) from Solnhofen: specimen in natural light (A), specimen in UV light (B) and line drawing (C); D, specimen MNHN.F.B13445 of Pustulina minuta (Schlotheim, 1822) from Solnhofen in UV light. Abbreviations: a1, antennule; a2, antenna; e, eye; Mxp3, third maxillipeds; P1-P5, periopods 1 to 5. Scale bars: A-C, 1 cm; D, 0.5 cm. Photographs: L. Cazes. Line drawing: J. Devillez. 

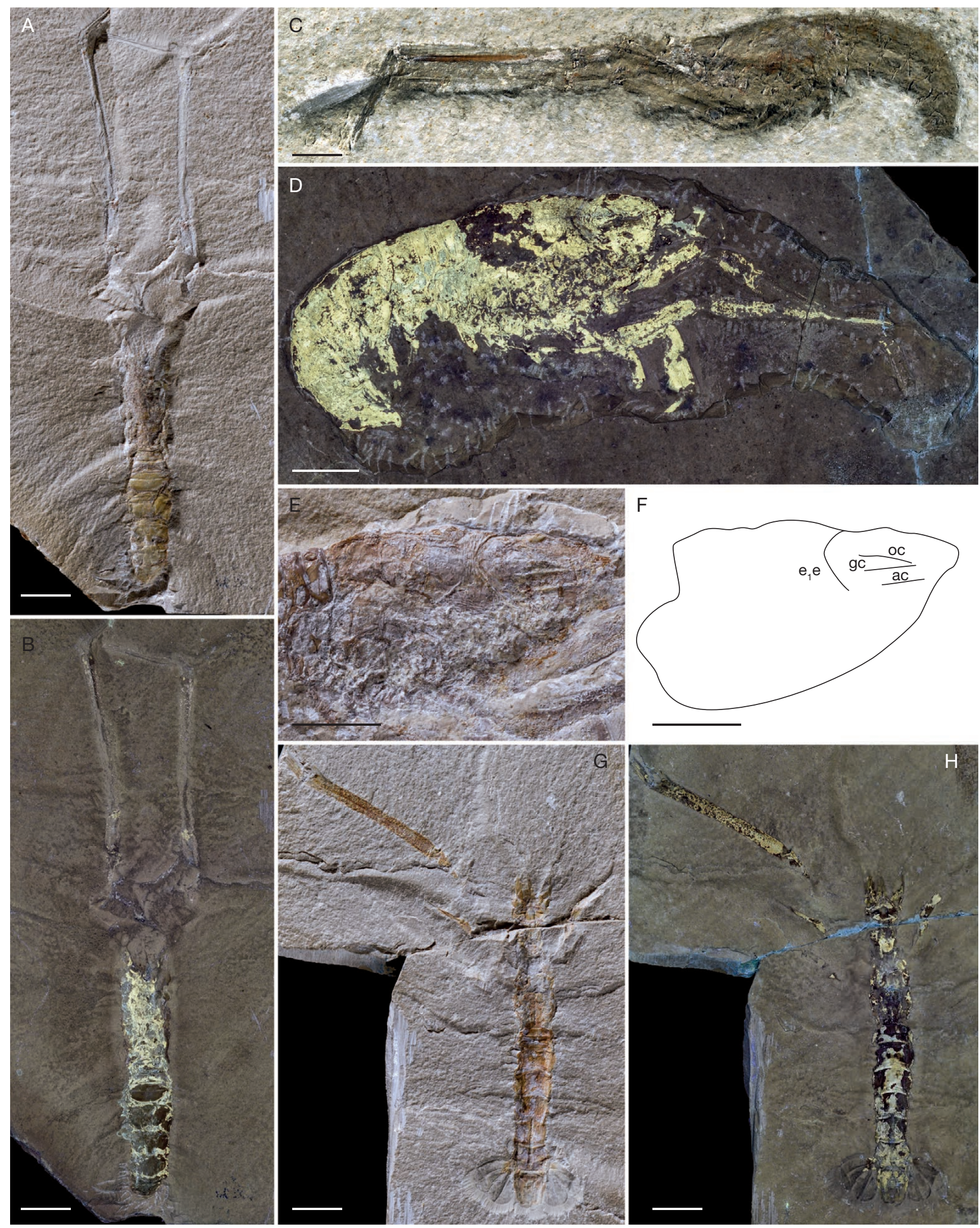

FIG. 8. - Mecochirus longimanatus (Schlotheim, 1820): A, B, specimen MNHN.F.A33537; A, specimen in natural light; B, specimen in UV light; C, specimen MNHN.F.B13457; D-F, specimen MNHN.F.A70929; D, general view in UV light; E, view of the carapace in natural light; $\mathbf{F}$, line drawing of the carapace; G, H, specimen MNHN.F.A33539; G, specimen in natural light; $\mathbf{H}$, specimen in UV light. Abbreviations: ac, antennal carina; $\mathbf{e}_{\mathbf{1}} \mathbf{e}$, cervical groove; gc, gastro-orbital carina; oc, orbital carina. Scale bars: $1 \mathrm{~cm}$. Photographs: L. Cazes. Line drawing: G.P. Odin. 

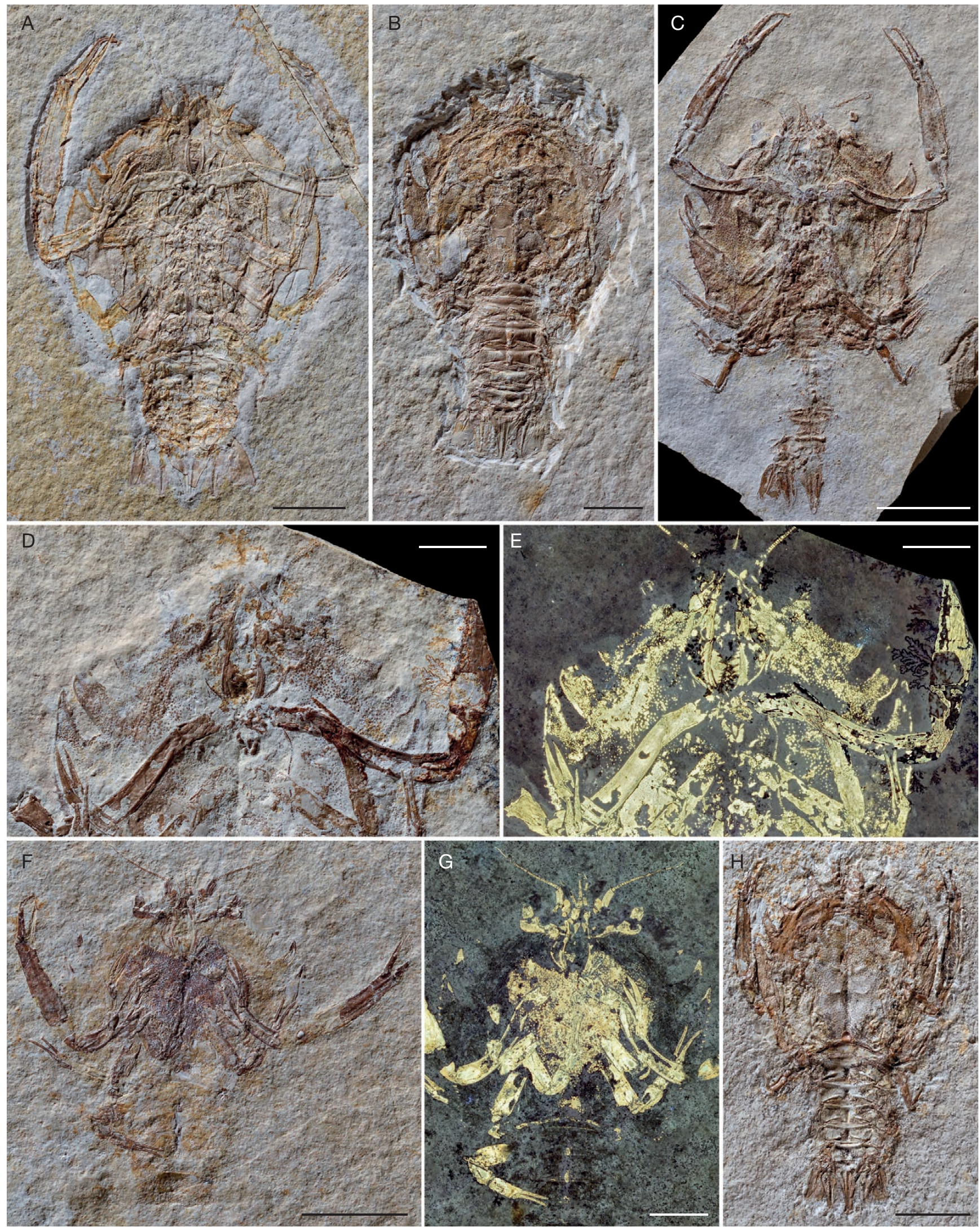

FIG. 9. - A, Cycleryon propinquus (Schlotheim, 1822): specimen MNHN.F.B13436 from Solnhofen; B-H, Eryon cuvieri Desmarest, 1817 : B, specimen MNHN.F.A33501 from Solnhofen; C, specimen MNHN.GG.2004/8218 from Solnhofen area; this specimen was referred to as coming from Pappenheim; since there are no Solnhofen Lithographic Limestones there, while many traders lived there, this specimen was probably purchased in Pappenheim; D, E, specimen MNHN.GG.2004/8220 from Solnhofen, natural light (D) and UV light (E); F, G, specimen MNHN.F.A33545 from Solnhofen, natural light (F) and UV light (G); H, specimen MNHN.F.B13439 from unknown locality. Scale bars: A, C, F, H, 2 cm; B, D, E, F, $1 \mathrm{~cm}$. Photographs: L. Cazes. 


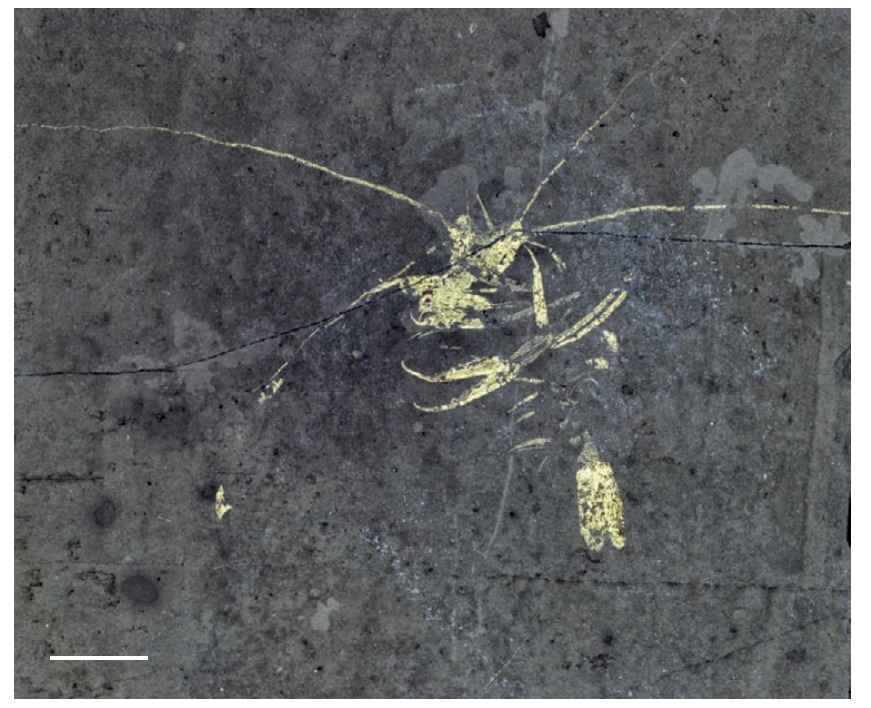

FIG. 10. - Elder ungulatus (Münster, 1839). Specimen MNHN.F.A33549 under UV light. Scale bar: $1 \mathrm{~cm}$. Photograph: L. Cazes.

the mandibles exhibiting sharp triangular teeth of uneven size (specimen MNHN.F.GG2004/8220; Fig. 9D, E). Indeed, the preservation is usually excellent: the antennae, antennules and eyestalks of the specimens MNHN.F.A33545 and GG2004/8218 are clearly visible and they exhibit between eight and ten pereiopods. The dorsally preserved specimen MNHN.F.B13439 (Fig. 9H) is also well-preserved and evidences delicate details on the carapace (branchiocardiac, postcervical and cervical grooves), telson (ponctuations and carinae). The other specimen (A33501; Fig. 9B) present some calcite bundles on the left chela.

\section{Superorder PERACARIDA Calman, 1904 \\ Order MYSIDACEA Boas, 1883 \\ Suborder and Family uncertain}

Genus Elder Münster, 1839

TYPE SPECIES. - Elder ungulatus Münster, 1839, by subsequent designation of Oppel (1862).

Elder ungulatus Münster, 1839

(Fig. 10)

STUDIED MATERIAL. — Charbonnier \& Garassino (2012) listed three specimens from Solnhofen (MNHN.F.A33549, B13467; MNHN. GG.2004/8217) but figured none. We do not change their contribution.

\section{COMMENTS}

Specimen MNHN.F.A33549 (Fig. 10) presents some pereiopods with terminal dactylus, some pleopods, the tail fan, and the hooked rostrum, which is isolated from the body. The carapace (cephalothoracic shield) is not preserved, neither the pleon. This configuration evokes an exuvia or a predated specimen. Intriguingly, some pereiopods exhibit apodemes as if the muscles were stripped off.
Class MEROSTOMATA Dana, 1852

Order XIPHOSURIDA Latreille, 1802

Family LIMULIDAE Riek \& Gill, 1971

Genus Mesolimulus Størmer, 1952

TyPE SPECIES. — Limulus walchii Desmarest, 1817, by monotypy.

Mesolimulus walchii (Desmarest, 1817)

(Fig. 11)

STUDiED MATERIAL. - Charbonnier \& Garassino (2012) listed four specimens from Solnhofen (MNHN.F.A33516, B13432, B13433; MNHN.GG.2004/7473) but figured only one specimen (MNHN.F.A33516). We do not change their contribution.

\section{COMMENTS}

Specimen MNHN.F.B13432 (Fig. 11A) is poorly preserved and exhibit many calcite bundles (as dumbells and spheres), mostly at the rear of the prosoma. According to Briggs \& Wilby (1996), among the arthropods of Solnhofen, Mesolimulus is the taxon the most commonly subject to calcite crystals bundles development (we illustrate a specimen of Eryon cuvieri with calcite bundles on Fig. 9B). Such crystals are believed to be formed during the early stage of diagenesis, due to microbial activity. Specimen MNHN.F.B13433 (Fig. 11B) is a dorsal view of a slightly deformed specimen; the prosoma, carapace and telson are beautifully preserved.

\section{Acknowledgements}

We thank Lilian Cazes (CR2P, MNHN) for assistance in photographic work. This paper is a contribution from the UMR CNRS 7207 Centre de Recherche en Paléontologie Paris, and part of the 'PyrEx' project, funded by the DIM Matériaux Anciens et Patrimoniaux. We also would like to thank Denis Audo and Alessandro Garassino for their useful comments on a previous version of the manuscript.

\section{REFERENCES}

Arratia G., Schultze H.-P., Tischlinger H. \& Viohl G. 2015. - Solnhofen - Ein Fenster in die Jurazeit. Dr. Friedrich Pfeil, München, 620 p.

Audo D. 2014. - Les Polychelida, un groupe de crustacés énigmatiques: systématique, histoire évolutive, paléoécologie et paléoenvironnements. $\mathrm{PhD}$ thesis, MNHN.

Audo D., Charbonnier S., Schweigert G. \& Saint Martin J.-P. 2014a. - New eryonid crustaceans from the Late Jurassic Lagerstätten of Cerin (France), Canjuers (France), Wattendorf (Germany) and Zandt (Germany). Journal of Systematic Palaeontology 12: 459-479. https://doi.org/10.1080/14772019.2013.777809

Audo D., Schweigert G., Haug J. T., Haug C., Saint Martin J.-P. \& Charbonnier S. 2014b. - Diversity and palaeoecology of the enigmatic genus Knebelia (Eucrustacea, Decapoda, Eryonidae) from Upper Jurassic Plattenkalks in southern Germany. Palaeontology 57: 397-416. https://doi.org/10.1111/pala.12071

Barthel K. W., Swinburne N. H. M. \& Conway Morris S. 1990. - Solnhofen, a Study in Mesozoic Palaeontology. Cambridge University Press, Cambridge, 236 p. 

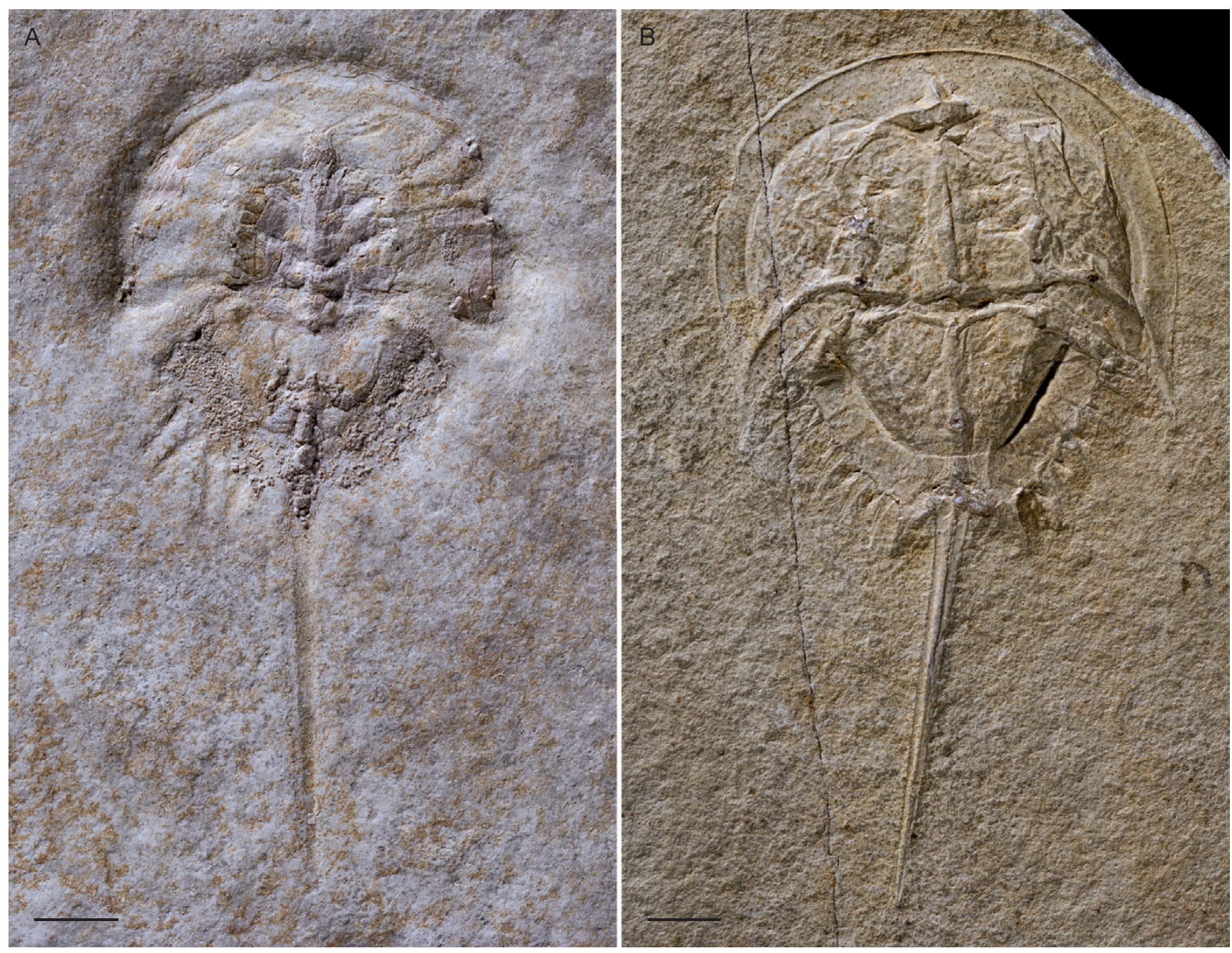

FIG. 11. - Mesolimulus walchii (Desmarest, 1817): A, specimen MNHN.F.B13432; B, specimen MNHN.F.B13433. Scale bar: 1 cm. Photographs: L. Cazes.

BRIGGS D. E. G. \& Wilby P. R. 1996. - The role of the calcium carbonate-calcium phosphate switch in the mineralization of soft-bodied fossils. Journal of the Geological Society 153: 665-668. https://doi.org/10.1144/gsjgs.153.5.0665

Briggs D. E. G., Moore R., Shultz J. W. \& SChweigert G. 2005. Mineralization of soft-part anatomy and invading microbes in the horseshoe crab Mesolimulus from the Upper Jurassic Lagerstätte of Nusplingen, Germany. Proceedings of the Royal Society Series B 272: 627-632. https://doi.org/10.1098/rspb.2004.3006

British Museum of Natural History 1904. - The history of the collections contained in the Natural history departments of the British museum. British Museum of Natural History. 4 vols. https://doi.org/10.5962/bhl.title.20926

BuCH DE L. 1823. - Lettre à M. Alex. Brongniart, etc., sur le gisement des couches calcaires à empreintes de poissons et sur les Dolomies de la Franconie, in AUDEBARD (baron d'), Bulletin général et universel des annonces et nouvelles scientifiques. Tome II. Order of the Trustees, Paris: 47, 48. https://biodiversitylibrary.org/page/4425334

CHARBONNIER S. \& GARASSINO A. 2012. - The marine arthropods from the Solnhofen Lithographic Limestones (Late Jurassic, Germany) in the collections of the Muséum national d'Histoire naturelle, Paris. Geodiversitas 34 (4): 857-872. https://doi.org/10.5252/g2012n4a8

Charbonnier S., Audo D., GARASSINO A. \& HYŽNY̌ M. 2017. Fossil Crustacea of Lebanon. Muséum national d'Histoire naturelle, Paris, 252 p. (Mémoires du Muséum national d'Histoire naturelle, vol. 210).
Desmarest A.-G. 1817. - Crustacés fossiles, in Société de Naturalistes et d'Agriculteurs (ed.), Nouveau Dictionnaire d'Histoire naturelle, appliquée aux Arts, à l'Agriculture, à l'Économie rurale et domestique, à la Médecine, etc. Tome 8 [COR-CUN]. Deterville, Paris: 495-519. https://biodiversitylibrary.org/page/18035624

DeSMAREST A.-G. 1822. - Les crustacés proprement dits, in Brongniart A. \& Desmarest A.-G. (eds), Histoire naturelle des crustacés fossiles sous les rapports zoologiques et géologiques. F.-G. Levrault, Paris: 67-142. https://biodiversitylibrary.org/ page/ 9656542

Devillez J., Charbonnier S., HyžnÝ M. \& Leroy L. 2016. Review of the Early Cretaceous erymid lobsters (Crustacea: Decapoda) from the Western Tethys. Geodiversitas 38 (4): 515 542. https://doi.org/10.5252/g2016n4a4

Devillez J. \& Charbonnier S. 2017. - The genus Eryma Meyer, 1840 (Crustacea: Decapoda: Erymidae): new synonyms, systematic and stratigraphic implications. Bulletin de la Société géologique de France 188 (3): art. 15. https://doi.org/10.1051/bsgf/2017178

Dietl G. \& SCHWEIGERT G. 2004. — The Nusplingen Lithographic Limestone - A 'fossil Lagerstaette' of late Kimmeridgian age from the Swabian Alb (Germany). Rivista Italiana di Paleontologia e Stratgrafia 110: 303-309. https://doi.org/10.13130/20394942/6302

Dietl G. \& SCHWeigerT G. 2011. - Im Reich der Meerengel - Fossilien aus dem Nusplinger Plattenkalk. 2nd edition. Dr. Friedrich Pfeil, München, $144 \mathrm{p}$. 
FÖRSTER R. 1971. — Die Mecochiridae, eine spezialisierte Familie der mesozoischen Glypheoidea (Crustacea, Decapoda). Neues Jahrbuch für Geologie und Paläontologie, Abhandlungen 137: 396-421.

FrAAS O. 1855. - Beiträge zum obersten weissen Jura in Schwaben. Jahreshefte des Vereins für vaterländische Naturkunde in Württemberg 11: 77-107. https://biodiversitylibrary.org/page/8002503

GARASSINO A. \& SCHWEIGERT G. 2004. - Cycleryon wulfi n. sp. (Crustacea: Decapoda: Eryonidae) from the Upper Jurassic of Eichstätt (Bavaria, S Germany). Atti della Società italiana di Scienze naturali e del Museo civico di Storia naturale in Milano, 145 (2): 243-250.

Garassino A. \& SChWeigert G. 2006. - The Upper Jurassic Solnhofen decapod crustacean fauna: review of the types from old descriptions. Part I. Infraorders Astacidea, Thalassinidea, and Palinura. Memorie della Società italiana di Scienze naturali e del Museo civico di Storia naturale di Milano 34 (1): 1-64.

Glaessner M. F. 1929. - Crustacea Decapoda, in POMPECKJ J. F. (ed.), Fossilium Catalogus, I: Animalia. W. Junk, Paris, 41: 1-464.

Glaessner M. F. 1969. - Decapoda, in Moore R. C. (ed.), Part (R) Arthropoda 4: Treatise on Invertebrate Paleontology. Boulder, Geological Society of America and The University of Kansas: R399-R533.

LAURiaT-Rage A. 2002. — La collection d'Invertébrés fossile d'Alcide d'Orbigny et la salle d'Orbigny. Comptes rendu Palévol 1: 615-627. https://doi.org/10.1016/S1631-0683(02)00054-4

Mantell G. A. 1822. - The Fossils of the South Downs; or Illustrations of the Geology of Sussex. Lupton Relfe, 327 p. https:// doi.org/10.5962/bhl.title.44924

MAYER G. 1976. - Württembergische Paläontologen, vorzüglich Liebhaber (Sammler, Förderer, Populisatoren, Präparatoren), die im Catalogus bio-bibliographicus von Lambrecht und Quenstedt (1938) fehlen. Jahreshefte der Gesellschaft für Naturkunde in Württemberg 131: 50-124.

MeYer H. (VoN) 1835-1838. - Briefliche Mitteilungen, in LEONHARDT K. C. \& BRONN H. G. (eds), Neues Jahrbuch für Mineralogie, Geologie und Paläontologie. C.F. Winter, Stuttgart, 328 p.

MÜNSTER G. G. ZU 1839. — Decapoda Macroura, Abbildung und Beschreibung der fossilen langschwänzigen Krebse in den Kalkschiefern von Bayern. Commission der Buchner'schen Buchhandlung, Bayreuth: 1-88. https://doi.org/10.5962/bhl.title.120022

MÜNSTER G. G. ZU 1840. - Ueber einige Isopoden in den Kalkschiefern von Bayern, in Beiträge zur Petrefaktenkunde. Vol. 3. Commission der Buchner'schen Buchhandlung, Bayreuth: 19-23.

Oppel A. 1862. - Ueber jurassische Crustaceen (Decapoda macrura). Palaeontologische Mittheilungen aus dem Museum des koeniglich Bayerischen Staates 1: 1-120.

Robalino J., Wilkins B., Bracken-Grissom H. D., Chan T. Y. \& O'LEARY M. A. 2016. - The origin of large-bodied shrimp that dominate modern global aquaculture. PloS one 11: e0158840. https://doi.org/10.1371/journal.pone.0158840
SCHLOTHeim E. F. VON 1820. - Die Petrefactenkunde auf ihrem jetzigen Standpunkte durch die Beschreibung seiner Sammlung versteinerter und fossiler Uberreste des Thier-und Pflanzenreichs der Vorwelt erlautert. Becker, Gotha, $457 \mathrm{p}$.

SCHLOTHEIM E. F. VON 1822. — Beiträge zur näheren Bestimmung der versteinerten und fossilen Krebsarten. Nachträge zur Petrefaktenkunde, Becker, Gotha: 17-37.

SCHWEIGERT G. 2001. - Eine neue Art der Gattung Antrimpos Münster (Crustacea, Decapoda, Penaeidae) aus dem Nusplinger Plattenkalk (Oberjura, Ober-Kimmeridgium, SW-Deutschland). Staatliches Museum für Naturkunde, Serie B, 307: 1-33.

SCHWEIGERT G. 2007. - Ammonite biostratigraphy as a tool for dating Upper Jurassic lithographic limestones from South Germany - first results and open questions. Neues Jahrbuch für Geologie und Paläontologie, Abhandlungen 245: 117-125.

SCHWEIGERT G. 2011. - The decapod crustaceans of the Upper Jurassic Solnhofen Limestones: A historical review and some recent discoveries. Neues Jahrbuch für Geologie und Paläontologie, Abhandlungen 260: 131-140.

SCHWEIGERT G. 2015. - Zehnfußkrebse (Decapoda) und andere Krebstiere, in Arratia G., Schultze H.-P., Tischlinger H. \& VIOHL G. (eds), Solnhofen - Ein Fenster in die Jurazeit. Dr. Friedrich Pfeil, München: 271-291.

SCHWEIGERT G. 2017. — Die Garnele Antrimpos undenarius aus dem Nusplinger Plattenkalk (Ober-Kimmeridgium, Schwäbische Alb) und deren Rolle im dortigen Ökosystem. Archaeopteryx 34: 1-7.

SCHWEIGERT G. \& GARASSINO A. 2004. - New genera and species of shrimps (Crustacea: Decapoda: Dendrobranchiata, Caridea) from the Upper Jurassic lithographic limestones of S Germany. Stuttgarter Beiträge zur Naturkunde, Ser. B, 350: 1-33.

SCHWEIgerT G., Garassino A. \& PASINI G. 2016. — The Upper Jurassic Solnhofen decapod crustacean fauna: Review of the types from old descriptions. Part II. Superfamily Penaeoidea and infraorder Caridea. Memorie della Societa Italiana di Scienze Naturali e del Museo Civico di Storia Natural di Milano 49: 3-26.

SChWEItZer C., FeldMann R., GARASSINO A., KarasaWa H. \& SCHWEIGERT G. 2010. - Systematic List of Fossil Decapod Crustacean Species, BRILL. https://doi.org/10.1163/ej.9789004178915.i-222

SECRÉTAN S. 1968. - Mecochira foresti, nouveau Crustacé du Jurassique supérieur de Solnhofen. Annales de Paléontologie Invertébrés 54 (2): 227-238.

VAN STRaelen V. 1925. - Contribution à l'étude des crustacés décapodes de la période jurassique. Mémoires de la Classe des Sciences de l'Académie royale de Belgique 7: 1-462.

Winkler N. 2012. - Libanocaris annettae nov. sp. (Crustacea: Dendrobranchiata: Penaeidae) from the Upper Jurassic Solnhofen Lithographic Limestones of Eichstätt. Zitteliana A, 52: 59-65. https://doi.org/10.5282/ubm/epub.15296

Woods H. 1925-1931. - A Monograph of the Fossil Macrurous Crustacea of England. Palaeontographical Society of London, London, $122 \mathrm{p}$. 
APPENDIX 1. - List of the 117 specimens of marine arthropods coming from the Southern Germany Lithographic Limestones and housed in the MNHN, Paris. Bold, specimens newly described (this work); underligned, specimens re-attributed (this work); n, number of specimens; -, not observed.

Collection numbers

Total

\begin{tabular}{|c|c|c|c|c|c|}
\hline \multirow[b]{2}{*}{ Taxa } & \multicolumn{3}{|c|}{ Collection numbers } & \multirow[b]{2}{*}{$\mathbf{n}$} & \multirow{2}{*}{$\frac{\text { Tota }}{\mathbf{n}}$} \\
\hline & Charbonnier \& Garassino 2012 & $\mathbf{n}$ & This work & & \\
\hline \multicolumn{6}{|l|}{ DECAPODA } \\
\hline \multicolumn{6}{|l|}{ Aegeridae } \\
\hline Aeger spinipes (Desmarest, 1817) & MNHN.F.B13441 & 1 & MNHN.F.B13440, B13441, B13442 & 3 & 3 \\
\hline Aeger tipularius (Schlotheim, 1822) & $\begin{array}{l}\text { MNHN.F.A33509, B13440, B13442, } \\
\text { B13443, R03389; MNHN. } \\
\text { GG.2004/57291, 2004/8072 }\end{array}$ & 7 & $\begin{array}{l}\text { MNHN.F.A33509, B13443; MNHN. } \\
\text { GG.2004/8072 }\end{array}$ & 3 & 3 \\
\hline Aeger insignis Oppel, 1862 & & 0 & MNHN.GG.2004/57291 & 1 & 1 \\
\hline Acanthochirana longipes (Oppel, 1862) & MNHN.F.A42003 & 1 & & 0 & 0 \\
\hline Acanthochirana cordata (Münster, 1839) & & 0 & MNHN.F.A33503, A42003, R03389 & 3 & 3 \\
\hline \multicolumn{6}{|l|}{ Penaeidae } \\
\hline Antrimpos speciosus Münster, 1839 & $\begin{array}{l}\text { MNHN.F.A33504, A33519, A33548, } \\
\text { B13465, R03502; MNHN. } \\
\text { GG.2004/8086 }\end{array}$ & 6 & $\begin{array}{l}\text { MNHN.F.A33504, A33519, A33548, } \\
\text { B13465, R03502; MNHN. } \\
\text { GG.2004/8086 }\end{array}$ & 6 & 6 \\
\hline Antrimpos undenarius Schweigert, 2011 & & 0 & $\begin{array}{l}\text { MNHN.F.A06834, A49608, A49609, } \\
\text { A49610, A49615, A49616, } \\
\text { A49622, A49623, A49624 }\end{array}$ & 9 & 9 \\
\hline Rauna angusta Münster, 1839 & MNHN.F.A42004 & 1 & - & - & 1 \\
\hline Bylgia hexadon Münster, 1839 & MNHN.F.A33503 & 1 & & 0 & 0 \\
\hline $\begin{array}{l}\text { Albertoppelia kuempeli Schweigert \& } \\
\text { Garassino, } 2004\end{array}$ & MNHN.F.A33521 & 1 & - & - & 1 \\
\hline Drobna deformis Münster, 1839 & MNHN.F.A33531 & 1 & - & - & 1 \\
\hline \multicolumn{6}{|l|}{ Caridea } \\
\hline Hefriga serrata Münster, 1839 & $\begin{array}{l}\text { MNHN.F.B13464; MNHN. } \\
\text { GG.2004/8237 }\end{array}$ & 2 & - & - & 2 \\
\hline \multicolumn{6}{|l|}{ Erymidae } \\
\hline Eryma modestiforme (Schlotheim, 1822) & $\begin{array}{l}\text { MNHN.F.A33507, B13446, B13448, } \\
\text { B13450, B13452, B13463; MNHN. } \\
\text { GG.2004/7462, 2004/8078-7471 }\end{array}$ & 8 & $\begin{array}{l}\text { MNHN.F.A32408, A33507, A70905, } \\
\text { A70906, B13446, B13448, } \\
\text { B13450, B13452, B13463; MNHN. } \\
\text { GG.2004/7462, 2004/8078-7471 }\end{array}$ & 11 & 11 \\
\hline Palaeastacus fuciformis (Schlotheim, 1822) & $\begin{array}{l}\text { MNHN.F.B13449; MNHN. } \\
\text { GG.2004/8245, 2004/7998-8106 }\end{array}$ & 3 & $\begin{array}{l}\text { MNHN.F.B13449; MNHN. } \\
\text { GG.2004/8245, 2004/7998-8106 }\end{array}$ & 3 & 3 \\
\hline Pustulina minuta (Schlotheim, 1822) & $\begin{array}{l}\text { MNHN.F.B13444, B13445; MNHN. } \\
\text { GG.2004/8101 }\end{array}$ & 3 & $\begin{array}{l}\text { MNHN.F.B13444, B13445; MNHN. } \\
\text { GG.2004/8101 }\end{array}$ & 3 & 3 \\
\hline \multicolumn{6}{|l|}{ Glypheidae } \\
\hline $\begin{array}{l}\text { Glyphea pseudoscyllarus } \\
\text { (Schlotheim, 1822) }\end{array}$ & $\begin{array}{l}\text { MNHN.F.A33506, B13447, B13462; } \\
\text { MNHN.GG.2004/7463 }\end{array}$ & 4 & - & - & 4 \\
\hline \multicolumn{6}{|l|}{ Mecochiridae } \\
\hline $\begin{array}{l}\text { Mecochirus longimanatus (Schlotheim, } \\
\text { 1820) }\end{array}$ & $\begin{array}{l}\text { MNHN.F.A33508, A33533, A33534, } \\
\text { A33535,A33536, A33537, A33538, } \\
\text { A33539, A33540, A33541, A33542 } \\
\text { A33546, A42005, A42007, B13453, } \\
\text { B13454, B13456, B13457, } \\
\text { R03397; MNHN.GG.2004/7461, } \\
\text { 2004/8073, 2004/8075, 2004/8080, } \\
\text { 2004/8081, 2004/8102, 2004/8232, } \\
\text { 2004/8231 }\end{array}$ & 27 & $\begin{array}{l}\text { MNHN.F.A33508, A33533, A33534, } \\
\text { A33535, A33536, A33537, } \\
\text { A33538, A33539, A33540, A33541, } \\
\text { A33542 A33546, A42005, A42007, } \\
\text { A70929, B13453, B13454, } \\
\text { B13456, B13457, R03397; MNHN. } \\
\text { GG.2004/7461, 2004/8073, } \\
\text { 2004/8075, 2004/8080, 2004/8081, } \\
\text { 2004/8102, 2004/8232, 2004/8231 }\end{array}$ & 28 & 28 \\
\hline \multicolumn{6}{|l|}{ Palinuridae } \\
\hline Palinurina longipes (Münster, 1839) & $\begin{array}{l}\text { MNHN.F.A30691, A30773, A33510, } \\
\text { A33511, A33512, B13455, B13458, } \\
\text { B13460 }\end{array}$ & 8 & - & - & 8 \\
\hline \multicolumn{6}{|l|}{ Eryonidae } \\
\hline Cycleryon propinquus (Schlotheim, 1822) & $\begin{array}{l}\text { MNHN.F.A33518, A33543, A42006, } \\
\text { B13436; MNHN.GG.2004/8071 }\end{array}$ & 5 & $\begin{array}{l}\text { MNHN.F.A33518, A33543, A42006, } \\
\text { B13436; MNHN.GG.2004/8071 }\end{array}$ & 5 & 5 \\
\hline Cycleryon orbiculatus (Münster, 1839) & MNHN.F.B13434 & 1 & MNHN.F.B13434 & 1 & 1 \\
\hline Eryon cuvieri (Desmarest, 1817) & $\begin{array}{l}\text { MNHN.F.A32407, A33501, A33520, } \\
\text { A33544, A33545, B13437, B13438, } \\
\text { B13439, B13451, R03402, } \\
\text { R65101; MNHN.GG.2004/7997, } \\
\text { 2004/8109, 2004/8004, 2004/8218, } \\
\text { 2004/8220 }\end{array}$ & 16 & $\begin{array}{l}\text { MNHN.F.A32407, A33501, A33520, } \\
\text { A33544, A33545, B13437, B13438, } \\
\text { B13439 B13451, R03402, R65101; } \\
\text { MNHN.GG.2004/7997, 2004/8109, } \\
\text { 2004/8004, 2004/8218, 2004/8220 }\end{array}$ & 16 & 16 \\
\hline
\end{tabular}


APPENDIX 1. - Continuation.

\begin{tabular}{|c|c|c|c|c|c|}
\hline \multirow[b]{2}{*}{ Taxa } & \multicolumn{3}{|c|}{ Collection numbers } & \multirow[b]{2}{*}{$\mathbf{n}$} & \multirow{2}{*}{$\frac{\text { Total }}{n}$} \\
\hline & Charbonnier \& Garassino 2012 & $\mathbf{n}$ & This work & & \\
\hline \multicolumn{6}{|l|}{ STOMATOPODA } \\
\hline \multicolumn{6}{|l|}{ Sculdidae } \\
\hline Sculda pennata Münster, 1840 & MNHN.F.B13466 & 1 & - & - & 1 \\
\hline \multicolumn{6}{|l|}{ MYSIDACEA } \\
\hline \multicolumn{6}{|l|}{ Mysidacea } \\
\hline Elder ungulatus (Münster, 1839) & $\begin{array}{l}\text { MNHN.F.A33549, B13467; } \\
\text { MNHN.GG.2004/8217 }\end{array}$ & 3 & $\begin{array}{c}\text { MNHN.F.A33549, B13467; } \\
\text { MNHN.GG.2004/8217 }\end{array}$ & 3 & 3 \\
\hline \multicolumn{6}{|l|}{ XIPHOSURA } \\
\hline \multicolumn{6}{|l|}{ Lumulidae } \\
\hline Mesolimulus walchii (Desmarest, 1817) & $\begin{array}{l}\text { MNHN.F.A33516, B13432, B13433; } \\
\text { MNHN.GG.2004/747 }\end{array}$ & 4 & $\begin{array}{l}\text { MNHN.F.A33516, B13432, B13433; } \\
\text { MNHN.GG.2004/747 }\end{array}$ & 4 & 4 \\
\hline TOTAL & & 104 & & 99 & 117 \\
\hline
\end{tabular}

